\title{
The Luso-Spanish Composite Global Empire, 1598-1640
}

The impact of globalization upon the Iberian complex becomes even clearer when we look at the way the imperial systems were created and interlinked, as well as at the evolution of the global forces in which they were embedded. This perspective also implies a study of the way imperial institutions operated and how social networks on a global scale interacted with the formal institutions created by the Crown to try to impose its authority and to control different agents' agendas.

\section{The Iberian Complex in a Global Perspective}

\section{Two Empires and One World}

Recent historiography has underlined, with good reason, the numerous interconnections between the Spanish and Portuguese empires (Subrahmanyam 2007; Bethencourt 2013; Borges 2014; Herzog 2015). Certainly, in institutional terms both empires maintained the rule of their respective institutional systems and implicit codes of practice. Portuguese subjects of the Habsburgs could not enter directly into Castile's commerce with America; Castilians, like subjects of the peninsula's other kingdoms, were classified as foreigners in Portuguese territories ruled by the same dynasty.

The Council of Portugal, in Madrid, was charged with providing advice on the management of Portuguese overseas possessions, and the Council

B. Yun-Casalilla, Iberian World Empires and the Globalization of Europe 1415-1668, Palgrave Studies in Comparative Global History, https://doi.org/10.1007/978-981-13-0833-8_7 
of the Indies oversaw affairs relative to the Spanish colonies. The Casa de la Contratación of Seville and the Casa da Índia of Lisbon, two very similar institutions, operated, however, with total independence of each other. The same can be said of other institutions with colonial reach and impact, such as the Inquisition. Though one can recognize the sharing of an administrative culture similar in some respects as well as the exchange of information in some fields, the two organizations acted as separate bodies in Spain and Portugal (Bethencourt 2009). Likewise, the respective branches of the Catholic Church comprised separate organizations, in particular in regard to the exercise of patronage rights and the appointment of bishops, and so on. And the same can be said about the transfers of money and military resources between the two kingdoms, at least from a formal and juridical perspective. The problem of the transfer of funds between kingdoms in order to defend each other's interests had not abated.

Nevertheless, on occasions this formal separation could be overlooked. At the very beginning of the union of the two Crowns, in 1583, an expedition to the Azores had been financed with Castilian and Neapolitan money, while Portugal was involved in the Invincible Armada (Thompson 1976). Similar situations, in which joint contributions served the interests of one kingdom, would occur over the coming years, as in the recovery of Bahia in 1625 . But combined operations would be a cause of controversy. In fact, the Portuguese, who had never previously been involved in this sort of venture, claimed that they contravened the terms of the Cortes of Tomar (1581). Moreover, in time the Castilians would make the same claim (Feros 2000, pp. 159-161).

This having been said, the binding or entwining of the Portuguese and Spanish empires would gather pace after 1580 (Herzog 2015). Thus, when in 1641 the governor of Buenos Aires received the royal order to expel the Portuguese for fear of 'contagion' of the rebellion in their homeland, a member of the city elite responded with a strong argument: this decree, he averred, broke up 'marriages', preventing husbands from 'living a marital life with our wives' (quoted by Trujillo 2009, 350).

This entwining of Iberians was in many respects the result of two global phenomena, which are normally studied as separate processes but which were in fact very much linked: the development of new avenues of Portuguese trade with Asia from the 1580s onwards and the silver mining boom in America after the 1560s. 
The first process is well known thanks to the excellent studies of Boyajian (1983 and 1993). According to this author, even if pepper continued to be the most demanded product, a generation of New Christians emerged who took advantage of the Crown's need to broaden the trade into products such as Chinese and Indian cottons, silks, porcelain, diamonds, precious pearls, cinnamon, exotic perfumes, indigo, and even exquisite Asian furniture. This trade, it is important to note, was sometimes diverted from the African to the American coast, arriving in Brazil and, increasingly, in Río de la Plata (Studnicki-Gizbert 2007). The second process, the silver boom, was in a certain way a precedent and a cause of this new commercial development. Since the 1560s what Chaunu called the 'inter-cycle recession' of the fifties (Chaunu 1959, pp. 255-352) was overcome, and the discovery of new deposits, as well as technological advances, provoked a new boom in the production of silver in America that would last until the first decades of the seventeenth century (Bakewell 1990, p. 81 and Hamilton 1975, p. 47). The flow of American silver and the difficulty in matching Portuguese imports from Asia with African gold made the Portuguese more keen to secure this precious metal, which they were already using in their Seville connection. Thus, through Brazil, the Portuguese began to obtain a significant part of the available Peruvian silver in exchange for increasing quantities of African slaves, supplying the basis of the plantation economy. Then, shortly afterwards, a portion of this precious metal was diverted towards the Río de la Plata. In fact, these exchanges were not only based on the trade in slaves but also on that of other less well-known products, such as Indian cotton (Boyajian 1993; Russell-Wood 1992; Studnicki-Gizbert 2007).

The impact of these two trends was crucial, and some facets of it have been mentioned already. The silver boom came hand in hand with the development of the plantation economy and the increasing export to Europe of products from these ventures. For this reason, American trade was becoming richer and more diversified. But this development also enhanced, as we have seen, the connections with Northern Europe, from which increasing quantities of goods were brought to Iberia and exported from it to the colonies (particularly America), with more silver and Asian commodities being exported to the northern half of the old continent. It is not, therefore, surprising that the old theory about a decline in Asian trade in the second half of the sixteenth century is not 
accepted today (Boyajian 1993), and recent estimates of Portuguese shipping to Asia corroborate this revisionism. ${ }^{1}$

This same process facilitated the growing dynamism of a new route towards globalization: commerce between New Spain (Acapulco) and the Philippines (Manila) that completed the silver belt around the world and allowed Asian products to reach Mexico-whence some were sent on to Seville and Europe in general-in exchange for silver from New Spain. This route even skirted the Pacific coastlines of America, reaching down as far as Peru where Asian products were sold in return for that area's silver. American silver, being of greater purity-and therefore value-than Japanese silver, even allowed for the reduction of the importance of Japanese trade in China, thus adding to Portuguese power in the China Sea. This trade, like others of its time, did not only depend upon merchants in the strict sense of the word; rather exchanges were conducted also by soldiers, adventurers, and above all missionaries who obtained notable profits (Gasch 2012, Palomo 2016). And this was also the case in the commerce between the Philippines and Acapulco (Gasch 2012).

This new trend also impacted the Iberian Peninsula. The presence of Portuguese in Andalusia, and above all in Seville and Córdoba, increased (Studnicki-Gizbert 2007; Fortea 1981). The links between the Portuguese and the Duero Valley trade (connected to both Seville and Lisbon) were reinforced and were even one of the reasons for the positive reaction of the Castilian fairs, which prolonged their life until the end of the century in some cases (Yun 1987). By 1580 the circulation of Castilian silver in Portugal, and with it the influence of its economy, was bringing about a noticeable Castilianization of the Portuguese economy (Disney 2009).

All this explains how and why the interlinking of Portuguese and Castilians increased in this epoch in the colonial arena, as has been underlined (Subrahmanyam 2007). But-and this is often forgotten-the same interlinking occurred on the Iberian Peninsula. Both Castilians and Portuguese created settled personal relationships and trust networks based upon common interests. At this point the formal institutions of the two

\footnotetext{
${ }^{1}$ The available estimates show that the number of Portuguese ships sailing from Lisbon to Asia was revitalized from 1570, following a slight dip in numbers in previous years. This trend would reach its peak between 1601 and 1610 (despite attacks from the United Provinces) and was maintained at a very high level until 1620. Very meaningfully, Portuguese voyages therefore followed the same cycle as the arrival of American silver in Seville (Duncan 1986).
} 
empires had more or less clearly defined frontiers. But the cross-border character of their connections was a fact. This does not mean that tensions were absent. On the contrary, contact itself was creating conflicts. But these were two empires in an increasingly interconnected world. As we shall see, this was not a closed system fully controlled from above; nor was it a massive trade grid capable of producing a strong convergence of prices at the global level (O'Rourke and Williamson 2002). Nevertheless, the ensuing connections would be decisive for the history of the Spanish and Portuguese empires and for the working of their political economies.

\section{The Problem of Information}

The issues outlined above are essential to identifying the great problems of the Luso-Spanish imperial complex, as well as the principles that governed its political economy and brought about a profound transformation in it from 1600 onwards.

One essential, recurring issue regarded information, the slowness of its circulation, the problems in obtaining it, and the consequent difficulties for government and business. Governors were perfectly conscious of these issues and dreamt of obtaining what they called the 'complete notice', ('la entera noticia') (Brendecke 2012). But they also presented a grave problem for the individuals and, above all, for the merchants who flowed through the arteries of this empire.

The slow circulation of news was caused, logically, by the distances involved. The voyage between the metropolis and the closest colonies in the Atlantic was, in the case of the Spanish empire, some 13 weeks on the way out and 18 on the return, while in the case of the English empire, it would be between 5 to 8 weeks and 3 to 8 weeks, respectively, according to the route chosen (Elliott 2006, pp. 177 and 181). The problem was even greater in the case of the Portuguese empire, where the voyage from Lisbon to Goa might last as long as 24 weeks. Yet this was not even the major problem or principal difference with the British colonies to the North. Rather, the great difficulties sprang from the rhythm and rigidity in the circulation of reports upon which the organization of the Carrera de Indias depended, which in turn was caused by the climate and rhythm of the seasons, winds and tides, and so on. While the English empire depended upon voyages that were much more staggered and frequent over the course of the year until at least the end of the seventeenth century, the Spanish depended upon fleets that could travel to the Caribbean 
only twice a year and return only at the end of the summer following the timetable already set out (Chap. 2). A similar situation affected Portugal on account of the monsoons (Parry 1990, chapters 6 and 7). For this reason, the communication systems (essential for political and business organizations) that crossed over and between these areas faced considerable difficulties. If ships departed from Lisbon in March, even with fair winds, they would not arrive in Goa until September, and they could only embark on their return journey towards January or February, arriving back in Portugal, if everything went well, in August or September of the year after their departure (Kellenbenz 2000, p. 602). That is to say that the information, instructions, and orders could be produced and sent from the headquarters of the Estado da India only once a year, and the arrival of responses in Lisbon might in theory take as long as 18 or 19 months.

Yet this was simply the first step, as within the colonies themselves, several weeks might be needed to communicate between the most distant parts of the empire and the Caribbean or Goa; for things to work well here, a perfect synchronization of voyages and climates and no little good fortune were necessary. It is not, therefore, surprising that letters written by emigrants were often filled with a terrible sense of isolation and disconnection. References abound to entire years in which communications with the Iberian Peninsula were interrupted, with insecurity flowing from the loss of correspondence or the unexplained disappearance of persons dispatched, while consternation was sometimes expressed about the plight of messengers sent to find people who were perhaps themselves in transit and therefore unlikely to be located. On 20 April 1592, one Pedro de la Huerta wrote to his nephew in response to a letter penned in September 1588, in which he complained of not having received any word from his uncle in almost four years. And in 1562 Diego Martín de Trujillo confessed that it had been more than 11 years since he had news of his family. These were two cases among hundreds that have survived (Otte 1988). And the same problem occurred in the royal administration that, despite a dense network of bureaucrats, informants, messengers, and mediators, still faced problems obtaining reliable and timely information (Brendecke 2012).

In this situation, the creation of oligopolistic circuits of privileged information gave their members certain advantages. One well-known example is that of the Dutch merchants who wrote their famous gazettes to Amsterdam recounting the details of American shipments to Spain even before the galleons arrived in Seville (Morineau 1985). The circuits created by consuls, nominally merchants, should be understood in the same light, 
and these were extended across many parts of Europe and very often operated according to an affinity based upon common origins, as was the case of the Italian or Jewish communities. For its part the Society of Jesus came to arrange an entire system for the exchange of information, the so-called 'Jesuit letters' (Broggio 2002). In reality many of these arrangements were alternatives to the existence of a postal or courier network, although something resembling one began to emerge in America at the beginning of the seventeenth century (Montáñez 1950). Throughout the sixteenth century, the letters of emigrants repeatedly refer to entrusting correspondence to the merchants and sailors who sailed the seas, a practice that entailed a high risk of loss and news blackout (Otte 1988). All of this can be taken as evidence of the high costs of information and the need to create networks of confidence based upon previous relations or mutual benefit that guaranteed the circulation and veracity of reports.

The consequences of this situation impacted governmental systems. Without doubt, government both depended upon and collected a multitude of reports, visits, and accounts, which presented a fuller picture of events than might otherwise have been obtained. The efforts of viceroys in both Asia and America provided a good demonstration of these phenomena (Merluzzi 2003, chapter 2). As we have seen, in both Crowns a number of centralizing projects were proposed, encompassing political organization as well as the news and information systems that facilitated the exercise of power. But the news that circulated through official channels was not always accurate, and many times the reports that reached Madrid (or Lisbon) provided 'not the truth, but rather indications of loyalty and disloyalty' (Brendecke 2012, p. 492). Because of these reasons, the result was a highly asymmetric information system that gave its mediators enormous power through its transmission and in particular favoured those who collected and advanced reports and news in situ, the price for which could only be paid through the cession of political capital which made it even more difficult for Madrid or Lisbon to implement the king's orders. The political economy of the empire would be highly affected by all of this.

\section{Social Networks and Informal Institutions in a Cross-Border Perspective}

The projection of elites across this global empire explains why, in part, imperial spaces across four continents very quickly became traversed by informal relationships that would prove decisive for their history. And this 
development was evident not only on the vast oceans, upon which historians have focused their attention, but also in Europe itself. This was, in many ways, a phenomenon that was unique to the period and of the fact that its politics had a corporate character.

The formation of these networks was often, but not always, an indirect consequence of possibilities for the social consolidation and extension of elites who had been present in the creation of the empire and in the process of globalization (Chap. 4). As we have said, these were social groups governed by two essential tensions-between solidarity and conflict and, at the same time, between the individual and the collective (see Chap. 1)and as such could do nothing but project these same rules of play upon the empire itself. If there was a certain tendency towards rupture among the branches of each continent, there was also an intention to maintain contacts. In some cases this desire was expressed through networks, where contact was essential for the interests of individuals, as would be the case for the Jewish merchants and financiers (Studnicki-Gizbert 2007). These traders formed genuine dispersed coalitions, transferring capital and merchandise among their members, and their only chance of survival lay in avoiding rupture and atomization. At times personal interest surfaced, as would happen with the priest in Castro del Río who corresponded with his brother and retained the letters in the hope of proving his right to the family inheritance (Hidalgo 2006). At other times, as perhaps occurred with the American branch of the Borja, these connections served as a way of maintaining and conserving this immaterial capital that belonged to the house; this was also manifested in the use of the shield of that lineage on coats of arms and ornaments (Redondo and Yun 2008).

These networks were based upon familial links and kinship, upon forms of recognizing prestige and reputation in the ways described by A. Greif (2006) for the case of Medieval Genoa. Family connections and ties with more distant relatives were a way to create confidence and circulate information. In America, nearly all correspondents of the Corzo and the Mañara, the leading Sevillian businessmen, belonged to their family or ended up being related to it (Vila 1991, passim). And often this meant persons who, while related, resided on different sides of the Atlantic. Moreover, dowries, often transferred across the Atlantic, were a form of moving family capital from the bride's side to the groom's and from one side of the ocean to the other (Almorza Hidalgo 2011). Similarly, the practice of standing as a godparent, very common in America, allowed a person - usually a family member or associate — to bind himself to another 
family in the act of baptism itself, thus creating links of great value for business designed to reinforce personal trust (Nutini and Bell 1980).

Family relations were often strengthened through education and training with or near to relatives, with the intention being that the parties, having reached maturity, would eventually work, trade, or operate together (see some examples in Vila 1991). Permanent ties of culture, identity, and belonging could likewise be decisive. This was, of course, the case for the Jewish merchants. And it was not uncommon to find affinities of language binding Italians or members of the same 'nation'. Even in the world of lawyers, support networks were sometimes formed that could operate as genuine lobbies active on the Iberian Peninsula and in America or Asia. And this was very possibly the case for many Portuguese merchant adventurers who, like Bartolomeu Landeiro, operated as intermediaries between the Portuguese and the Chinese, sometimes even serving the latter in a military capacity (de Sousa 2010; Boxer 1959). No less important were the simple friendships that sprouted up in any number of situations. The lawyers who formed relationships of this sort in their school days or during undergraduate studies at Castile's universities provide an example of such a group, while merchants generally established similar friendship networks, sometimes basing them on nothing more than mutual necessity (García Hernán 2007, passim; Vila 1991). ${ }^{2}$ Clientele and patronage relationships developed along similar lines, in particular between prominent persons such as viceroys and governors da Índia, who often belonged to the high aristocracy. In fact clientele practices-at times barely formalized in codes of external behaviour-could become decisive in a world much more inhospitable than that of the metropolis.

The result was often the formation of overlapping and flexible identities, as was logical in individuals who had two ways of conceiving themselves: as Jews and Portuguese, Castilians and Portuguese, or as belonging to a noble house, that is, to a lineage, while being subjects of a distant king in Madrid.

If the view from Europe necessarily entails the possibility of eurocentrism, then it is clear that the study of the connections within the colonies may provide a different perspective. The businessmen of the consulates of

\footnotetext{
${ }^{2}$ The case of J. de Solórzano is especially interesting (García Hernán 2007). In fact, if we review the contacts after his arrival in Peru, we find that, apart from extended family relations, a notable capacity to create 'friends', some of whom dated back to his time in Salamanca.
} 
Lima and Mexico were often connected with groups based in Castile or Flanders, and they served at the other end of the network, as important as its European part and, indeed, crucial to its very operation, as is clear from a careful reading of the work of Studnicki-Gizbert (2007). In light of recent studies, something similar might be said of the creole elite that, little by little, formed in America and that, more than representing the periphery of a web, performed at times as the centre of a constellation of relationships that were projected out into Asia (or, at times, from Asia) and towards Europe. A similar degree of ex-centrality can be found in the networks of converso merchants who operated in the trade between the Atlantic, Africa, and Asia, at times working in a way that their most important connections did not pass through Lisbon and even, on occasion, attempting to impose their conditions on Madrid, where they negotiated asientos and rented monopolies (Boyajian 1983 and Studnicki-Gizbert 2007).

Precisely because of the distances involved and the consequent problems of communication, the relationships formed in this way between individuals and groups could be fragile and easily broken. The death of members, oversight, or a lack of communication could fracture them and render them transitory, something that frequently happened. ${ }^{3}$ But these same dangers made these contacts even more necessary and led to their substitution and the replacing of defunct pacts and coalitions with great speed and efficiency. And these dangers afforded comparative advantages to the most solid networks, those based on family and those created by the Jews and which drew upon community identity, religion, social practices, cultural beliefs, and economic interests.

It is difficult to apply a single significance or historical effect to relations of this sort. Certainly, they were key to the conquest and functioning of empires. The lion's share of the available knowledge in military and economic affairs circulated through and along their branches, as did the political expertise that was crucial to making empire work. To give one example, military knowledge acquired in Europe by army captains and soldiers allowed for the wars of 'pacification' and conquest in America (Centenero 2009). And little remains to be said of the ability of Portuguese sailors to use the great advances of the incipient European military and naval revolution to serve their cause in Asia. Their knowledge of latest mining techniques allowed German emigrants to America to exploit the Peruvian and Mexican

\footnotetext{
${ }^{3}$ See different cases in Otte (1988).
} 
deposits that would irrigate the world with white metals (Sánchez 1989). It was in part thanks to the projection into America of German families such as the Welser and the Fugger, or many others of Genoese or Portuguese origin, that the Habsburg wars and their political system could be sustained. And, of course, the emergence of a certain type of law and a specific juridical culture - certainly, in this regard Portugal and Castile followed a very similar course, both originating in essentially the same university world - that created shared codes of legal and political behaviour that were subsequently extended across enormous territories (Rivero 2011). In other words, relationship networks were largely responsible for allowing armadas to sail and armies to fight; Audiencias, mines, cities, and viceroyalties were in large part also the result of networks of personal connections that, if they had their propulsive niche in these institutions, were fed in reality by informal relations appropriate to these networks of weak ties and links (see some examples in Centenero 2009).

But our interest, in any case, is the interaction with formal institutions and the means by which they interfered in both realities.

\section{'Perverting' 'Perverted' Institutions?}

As we have seen, informal networks were crucial for initial contacts in the different areas of both empires. Their development to a certain degree would create, however, a tension with the royal administrative and judicial apparatus, whose development was crucial in a gradually more competitive world where violence among the different polities would be the norm. The following pages try to explain this very important change and how such a tension would be decisive in a context of increasing globalization.

\section{Justice, Enforcement, and Distance}

The Crown would try to control the exercise of coercion, understood primarily in terms of justice and military organization through the creation of formal institutions (described above). The military defence was attempted primarily through the system of fleets and colonial squadrons, such as the Atlantic fleet (Armada del Mar Océano), the squadrons such as the Armada de Barlovento established by the Spaniards in America, or the maritime system that the Portuguese set up in Goa. In any case, this resulted in a strategic military presence that was intended to control the trade, regulate economic and social relations, and, in the final instance, wield the power of the king (Goodman 1997 and Phillips (1986). In this regard, the institu- 
tions mentioned above, such as the House of Trade of Seville (Casa de la Contratación de Sevilla) and the Casa da Índia, exercised, in theory at least, a high degree of power of enforcement to the extent that the 'monopoly' was organized through them. The same was true of the Portuguese Conselho da Fazenda (Miranda 2010). Attempts were made to exercise control over justice through the Audiencias and the Relaçoes, respectively (Tomás y Valiente 1982, Schwartz 1973, Hespanha 2001). Both cases constituted an attempt to apply and uphold the law in the colonies through a group of bureaucrats trained in peninsula law or, in the Spanish case, in the Indian Laws too (Chap. 2). As mentioned above, both empires proceeded to compile laws in the hope that their application in a clear and uniform way would serve to reduce risks and transaction costs. In the cities and American municipalities, as in the Portuguese câmaras and feitorias, an attempt was thus made to apply the king's justice.

It is not, however, surprising that the assessment of this situation from the perspective of the new institutional economics has been very negative (Coatsworth 2008). As occurred in the Iberian Peninsula, the efficiency of these institutions in regard to the creation of a centralized, transparent and predictable system for the exercise of coercion was highly relative. Both empires saw a plurality of agents who applied overlapping and, very often, clashing forms of coercion (Hespanha 2001, pp. 181-2). This is very evident in Portugal, where a scholar has spoken of an 'estatuto colonial múltiplo' (a multiple colonial status) to underline the administrative and jurisdictional pluralism of the system (Hespanha and Santos 1998, pp. 353-61). This was in part a consequence of a diverse range of situations that even led to the creation of seigniorial estates in the colonies (Neto 1997, pp. 154-55). But, in the Spanish system, the plurality of agents active in the exercise of coercion and power, often clashing among themselves, was also present.

By the same standard, the exercise of coercion was closely linked to the practices of social agents. Despite the efforts of the Crown to preserve the superiority of its authority, it was impossible to prevent the encomenderos and the owners of mines, mitas, and repartimientos, as well as the bandeirantes, the owners of slaves and plantations and even the owners of capitanias donatarias, from exercising their capacity for coercion on a day-to-day basis. Even, indeed, a number of religious institutions such as the Jesuits retained notable use of coercion, to judge by the many examples and cases found in the seventeenth century. This fact would even emerge in debates in which institutions such as the Audiencia of Lima 
became involved about the ownership of 'personal services', a euphemism for practices that entailed the enslavement of the Amerindians (Díaz 2010, pp. 108-120 and passim). Above all in the frontier areas, violence between the Crown's servants, Jesuits (and other ecclesiastical orders), and parts of the Indian population remained common (Ariel and Svriz 2016 and Monteiro 1994). Cases such as that of the bandeirantes in Brazil demonstrate both the vigour and prevalence of these customs of violence-as well as the weakness of royal authority-which were basic to the working of the overall system and, in particular, to obtaining a slave workforce for the emerging plantation economy (Monteiro 1994, pp. 138 and ff). Even a very hierarchical institution, such as the Inquisition, though it was "mixed' in nature' (a tribunal of the Crown but also an ecclesiastical tribunal), did not become completely integrated into the state's machinery (Bethencourt 2009, pp. 316 and ff). Not only could the Holy Office act quite independently in the implementation of justice, it could even interfere with the king's regular justice. Though, in theory, the Inquisition did not prosecute economic crimes, it could exacerbate a sense of risk and uncertainty among economic agents, which could affect economic activities and trade in particular.

Merchant sectors in the Iberian Peninsula had clearly achieved a privileged position (Chap. 5). Yet by the same standards, their counterparts in the empire were not that much different; in particular, this was true of the very powerful Consulates of Lima (1613) and Mexico (1592), behind which stood extremely influential groups of businessmen involved in both Europe and Asia. A number of individuals, such as Juan de Solórzano, who helped to found consulates as 'justice courts for merchant affairs', saw how they evolved into 'professional corporations of merchants, thus becoming a lobby within the viceroyalty’ (García Hernán 2007, p. 129). The information provided by J. L. Gasch (2015a) presents the modus operandi of the merchants of the Consulate of Mexico when faced with corruption in commerce with the Philippines. If the consulates themselves could positively reduce risks and transaction costs for their members, they could also fragment the map of conflict resolution and create barriers to the entrance of outsiders.

The forms of ownership established in the colonies were the opposite of what the new institutional economics considers the paradigm for efficiency. Although the Crown imposed and exercised its law in specific circumstances, a large part of property in both empires existed as a form of rights ceded by the king (Romano 2004). Moreover, property held in the 
privileged form of entailment was increasingly extended over time and led to the creation of lay and ecclesiastical elites in America. In this way a system was consecrated that not only placed obstacles before the circulation of land ownership but also advanced forms of management that were not always conducive to the implementation of productive improvements (Coatsworth 2008).

The political economy of the colonies was consequently characterized by the clash of forms of enforcement and by the importance of privilege and the opportunity to exercise violence as a substantial part of the productive relationships. All of this appears, on paper, a major problem for productive development and the efficient assignment of productive resources (North et al. 2009).

The imperial reality implied not only the adherence to local legal and normative codes but also systems that made distant institutions work and created forms of confidence and coercion in overseas spaces.

As occurred in the Iberian Peninsula, the Crown's scope for intervention as a third party in resolving conflicts was highly limited, although its role appeared to be guaranteed by the importance of the Audiencias and the authority of the viceroys and local authorities. In regard to lawsuits launched from the Iberian Peninsula, there were many problems. Enforcing compliance with contracts was sometimes complicated by the difficulty of locating persons or the time spent in doing so. In 1543 a Seville banker calculated that to prosecute a Fugger lawsuit in New Spain would require a year and a half (Kellenbenz 2000, p. 601). The execution of contracts by merchants involved in transatlantic trade was highly complex and required mechanisms of a mixed character. For example, Seville's merchants continually sent orders for unpaid debts to their operatives in America that appealed to the king's justice in the final instance (Cachero 2010). But, in order for them to arrive at that point, they themselves had to search for the debtors before these orders could be implemented. This revealed a form of justice that was accompanied by high transaction costs and that, by itself, had a limited capacity to reduce risks. And, if risks were fundamentally determined by other, more important factors (the chances of shipwreck, attack, appropriation by the king, the delay of the fleets, etc.), then forms of justice partly explain the high rates of maritime insurance (Bernal 1993). If, therefore, justice and enforcing compliance with contracts on the Iberian Peninsula were slow and there existed circuits outside of 'official' justice, to use the phrase of A. M. Hespanha, then the ramifications of this situation were even more emphatically felt in the immense world of 
global and local relations beyond it. For another thing, the very nature of a law that conceded a wide margin of manoeuvre to judges and entailed different jurisdictions meant that the problem was to know who was the 'best equipped to interpret and enforce the law' (Rivero 2011, p. 2011). In regard to the Estado da Índia, Hespanha has spoken of an extremely complex system in which seven areas of political jurisdiction were operative (Hespanha and Santos 1998).

The entwining of the two empires and their projection over extremely distinct societies increased the diverse range of moral and social codes, thus making it more difficult for official justice to penetrate the intricate social fabric and compelling it to highly complex cultural translations between the different social agents. This was the case in America, where the slow configuration of the 'caste society' (a term that is more a social representation than anything else) took place; it was also the case in the Portuguese dominions in Asia, where the frontier and the numerous cultures with whom they dealt was complex and porous.

\section{Dominant Coalitions, Patronage, Rent-Seeking, Corruption, Fraud, and Contraband}

These trans-frontier networks and webs cannot be understood as separate from the formation of elites and dominant coalitions of a local character. Indeed, the precise opposite was the case. Logically these webs acquired different characteristics according to the specific contexts in which they were born and their relations with the Crown. ${ }^{4}$ Notable differences also existed in the weight they could bring to the negotiating table and their influence. They were especially powerful and influential in areas such as New Spain or the viceroyalty of Peru. Here minorities of powerful creoles concentrated, often being linked to the exploitation of mines, the great estates or haciendas, trade, and the bank that, enjoying strong connections with the royal bureaucracy, exercised an enormous decision-making capacity (Bakewell 1995; Kicza 1999). Its vast economic potential was complemented by its very considerable social capital and its influential and charismatic identity as a creole minority whose character was deliberately projected to distinguish it from both the indigenous population and the Spanish (Gasch 2014). In part exploiting norms of consumption that

\footnotetext{
${ }^{4} \mathrm{~A}$ series of case studies is found in B. Ch. Büschges and B. Schrôter (eds.) (1999, pp. 10-82). The cases of Mexico and Río de la Plata, about which a great deal has been written, can be studied in Kicza (1999).
} 
included the use of Asian products as a means of cultural differentiation, these creoles proceeded to invent their own tradition by underlining their hybrid but unique identity. Their powers were extended through the system for the transfer of funds between regions through the situados, which conferred a degree of pre-eminence upon them. Theirs were the areas which most frequently transferred resources to the poorer regions with the aim of not only oiling the bureaucratic machinery but also-and above all-priming defence forces (Grafe and Irigoin 2012).

A series of features were repeated in practically all local elites, although in different combinations. As perhaps had to be the case, one of these was the use of matrimony and family and kinship relations as a means of constructing power. Here in fact lies one of the reasons why the family has always been credited with enormous importance in the history of social relations in Latin America. ${ }^{5}$ It could serve as a means of connection with the international networks mentioned above. In other instances relationships were based on occasional transfers of influence or of political and economic resources. The custom was that these networks of local relationships could call upon members who were strategically placed in politics, the bureaucracy, the magistrates, or business. This was a means of controlling diverse spaces that offered their different members a form of capital (economic, social, or cultural) that was easily interchangeable. And, despite there being no comparative study of this phenomena, the impression is that, if things were broadly similar on the Iberian Peninsula, the greatest weakness of the conception of a society of orders was that it conferred upon these elites a notable fluidity in the relations between their different component parts, above all through matrimony. It should be added that Portuguese colonial society in Asia passed through two phases in this regard. The first phase 'was characterised by the mobility of individuals' (Russell-Wood 1992, pp. 112-3). Figures such as Bartolomeu Landeiro or Fernando Mendes Pinto appear to have been continually on the move, being highly skilled and versatile operatives, blessed with a talent of obtaining information and selling it to the highest bidder while operating among local agents - a lifestyle and career, in short, indicative of their 'endemic individualism' (Russell-Wood 1992, p. 113; de Sousa 2010). But in a second phase, the presence of Jewish networks, marked by

\footnotetext{
${ }^{5}$ It is not surprising that the role of the family in the internal relationships between elites has been emphasized (Céspedes 2009, pp. 191-200).
} 
a strong familial character, must have created a broader panorama in this area and proven more similar to what had occurred in the Portuguese colonies in Brazil, which in turn can be said to have been very similar in this regard to the Spanish case (Studnicki-Gizbert 2007, chapter 3). This sequence does not mean, however, that both models were not present in the whole period under analysis here.

This type of network based on family and kinship would be vital, as it would prove to be crucial to one of the essential developments in the history of the empire-the increasing perversion of its formal institutions. By this I mean a process whereby these social networks and informal institutions would be able to take over many different institutions, such as the Audiencias, the municipal and ecclesiastical councils, the consulates, and many other institutions, and then impose upon them-and therefore upon the rest of the society - their own interests, ways of creating trust, and forms of enforcement. It is important to note that, as in the metropolis, this was also possible due to the 'unmodern' character (in the Weberian sense) of these administrative and political bodies. In a context in which the boundaries between public and private domains were highly permeable, this brought about a very high degree of concentration of political and economic capital, thus forging one of the key characteristics of the political economy of the colonies. Elite Mexican families, for example, were able to accumulate and unify their influence in the mines, the agrarian sector, local politics, the royal bureaucratic machinery, the Church, and so on and at the same time they were establishing international connections with Seville, Lima, the Caribbean, or the Philippines. These networks of interest were highly successful in penetrating the institutional system created by the monarchy. In these circumstances, which were far from unique, their chances of applying practices of rent-seeking were very high, to say the least. They had access to privileged information; were able to wield 'public' power to their own ends, and marshalled a highly solid economic base that allowed them to make transfers to members through the exercise of political and even juridical authority; and, finally, if all else failed, they could even shift the legal framework if they acted together as genuine coalitions.

Equally, their chances of indulging in fraud and corrupt practices were extensive, given that their international connections offered them enormous scope for contraband and commercial fraud. Patronage, clientelism, and corruption, in fact, were tied to the very model of the Iberian state, the character of the composite monarchy as a group of powers and jurisdictions 
linked together only in the person of the king (Yun 1994b). The outcome was the reproduction in an amplified and perfected form in the Indies of practices of nepotism, patronage, and so on. One of the best studies of the theme has identified the viceroys who arrived in the New World 'with a large retinue of family members and creatures' as an epicentre of corruption. This was tied not only to the centre of the political system, but also extended out into the localities and "periphery of the administration" (Pietschmann 1989, pp. 163-182). Existing studies have also shown that strong solidarities existed between royal officials and the owners of sugar refineries, which led to similar situations (Schwartz 1973). And yet the problem of corruption did not reside only in the negative impact of the misuse of public funds. Nepotism, the promotion of clients - then, as today, but more so in those societies in which clientelism was rooted in the essence of the social fabric and was part of the moral economy of the elitesdepended upon the use of human resources in the pursuit of private interest rather than that of the state. The dilemma between personal loyalty-so important in the codex of values of the period-and efficiency in state service was often resolved by placing the former ahead of the latter; obviously, this had important effects upon politics. In fact it was part of the political culture and practices of the epoch. At times corruption of this sort did not even necessarily require pre-existing family relationships, as it simply took root in the forms of payment and the cost of offices. Rather than focus on a very well-known field of study, such as the great bureaucrats who came to the colonies from the Iberian Peninsula, the example can be given of the repartimientos, which sometimes adopted a form of industrial verlagssystem. Patch's research has shown that the mayors (alcaldes mayores), being badly paid and in need of making good the money spent in buying their offices, fraudulently favoured the backer (aviador), a sort of verlaguer who had advanced money or primary material to the official and who thus obtained access to the forced labour of the Indians at a very low price (1994). Many variants of this sort of corruption can be found.

But the great problem-above all, as we shall see, in constructing a mercantilist empire or, simply, one based upon the control of the marketswas that one of the most important practices was contraband. This can be explained through the enormous power acquired by international networks of businessmen. But another factor was that these men, making use of their connections with local elites and functionaries, were able to pervert the working of the institutions. Moreover they found apt methods for doing so in the very institutions themselves. The renting of a state 
monopoly, the asientos of black slaves, and so on were means used by the very office holders themselves to facilitate fraudulent commerce; at other times these methods were exploited to exercise an unfair advantage over competitors, who might end up being removed or evicted from the sector in question (Studnicki-Gizbert 2007). Some time ago Zacarías Moutoukias provided information crucial to understanding another type of corrupt operation in the Río de la Plata and underlined the practical confusion that existed over what was legal and 'illegal' commerce. Indeed the multifunctional character of elites, in which functionaries mixed with merchants and their international connections raised smuggling to such levels that the monarchy had to 'legalize' it in return for money or the concession of privileges to its practitioners (Moutoukias 1988, chapter IV). The illegitimate thus became legal. A similar situation ensued in Cartagena and Veracruz where the collaboration of royal officials in the contraband networks has been very well described by J. M. Córdoba (2015). The same happened in Mexico, where members of the Consulate were awarded privileges in return for donations to the Crown of millions of pesos; these prerogatives granted them the right to discharge fiscal functions over their own shipments towards Asia (Gasch 2015a and 2015b). The method would also be applied in Seville and would be one of the keys to the so-called crisis of the Carrera de Indias, as we shall see. This admission - it might even be said, 'legalization' — of these practices in return for money testifies to the systemic character of corruption in the form of smuggling and contraband.

In these ways the networks of the empire had a series of characteristics: a pronounced family component, a marked prolongation of other forms of obtaining confidence, and a multilateral character spanning frontiers. It could also be made up of individuals belonging to many different 'nationalities' densely intermingled. In fact it is not difficult to see how in cases such as that of the Jewish networks of smugglers not only were the Spanish or Portuguese authorities involved in the subterfuge but so also were the English, Dutch, and French ones. In short, these were complex and multifunctional relationships. These agents had a notable capacity to prevent interference from the formal institutions which were, by their very nature, given to a sort of self-perversion; perhaps indeed, using the terminology built by Max Weber to describe modern societies, they can be considered as perverse. Though, the right way to express it beyond metaphors is to say that they were different and product of their own moment in history. In a global context, this would prove fatal to the state that sought to control this empire. All this does not mean that the Spanish and Portuguese 
administrative system was not subject to monitoring and control from the Crown. The visitas and other types of control were very common, and there are examples of major efforts against smuggling, fraud, and corruption (Bertrand 1999). But one needs to understand that contraband, fraud, rent-seeking, and corruption in general, often linked to nepotism and patronage as components of the prevalent political culture, were normal practices and a way to take advantage of previous investments in offices or to compensate poorly paid functionaries. In other words, corruption-particularly when it was 'legalized'-allowed the state to externalize a part of its very high protection costs.

\section{Corrosive Globalization}

The great enemy of the Luso-Spanish imperial complex was its own creation: the process of globalization, understood not only as the discovery and contact with new worlds but also as the increasing intertwining of distant societies.

\section{Globalization and Regional Economies}

The result of the colonization and 'globalization' of the New World was to encourage the emergence of new internal circuits in it, all of them linked at some point with the transcontinental routes. These were regional economies that, if they obeyed their own rules, were thoroughly interwoven into processes of globalization.

The development of the cities and mining settlements, both manifestations of a world that was ever more global, activated the need to provision them with products from nearby areas. In the seaboard of the Pacific, a coastal complex emerged that served to feed Peru, whose growth was carried forward by its globally important role in the extraction and circulation of silver (Mörner 1990, p. 143). The increase in internal American demand, a consequence of its connections to the global economy, helped the development of the plantation economy. The great estates or haciendas of Mexico, Argentina, or Brazil supplied products such as maize, livestock, or sugar cane, without which it would not have been possible to feed or send primary materials to the areas connected to Atlantic trade. Phenomena such as the efforts to colonize new lands or, more simply, the hunt for slaves carried the frontier slowly forward into the interior of Brazil; certainly the formation of great livestock breeding farms there can- 
not be understood without reference to these international connections (Lockhart and Schwartz 1983). In this way the new plantation economy, shaped by production destined for internal American consumption and which would come to compete with-and complement-the mining economy, was also a consequence of its expansion and the global connections of America. The great fairs of Veracruz, Jalapa, or Portobello, which were crucial for the long-range commerce of the Carrera de Indias, also became the stage for a growing regional commerce in the Caribbean that operated according to its own rules (Macleod 1990, pp. 180-8). The connections between the west coasts of Brazil and Argentina encouraged not only these regional trade systems but also the global circuits between Peru and the Río de la Plata (Assadourian 1982; Garavaglia 1983), which in turn inserted themselves into other circuits of commerce.

These regional circuits in the American continent have been considered as key to a debate on the possible existence of a seventeenth-century crisis (Israel 1974; TePaske and Klein 1981; Kamen and Israel 1982). But similar situations can be found in other zones of the planet. The South Atlantic, between the coasts of Guinea and the Ivory Coast, on the one side, and the coasts between the Caribbean and the Río de la Plata, on the other side, constituted a subsystem within global commerce (Russell-Wood 1992; Boyajian 1993). Similar circuits had developed, sometimes being built upon regional economies already linked before the arrival of the Europeans, between the Cape of Good Hope and Japan, where there existed regional economies with a certain degree of autonomy and in which Portuguese penetration was necessarily limited (Subrahmanyam 1990). The China Sea was an area with its own logic, where the silver from Japan was secured in exchange for all types of product to feed regional commerce (Flynn and Giraldez 2002). An idea of the importance of the regional circuits (not separated from the very long distance trade) can be gained from calculations that postulate that even in the moment of peak export of American silver to the Pacific (1600-1640), it did not constitute more than 10-25\% of the Japanese silver exported to China in compensation for its products (Barrett 1990, p. 246). Regional circuits were, therefore, more important in volume than long-distance and intercontinental trade.

Without doubt the penetration of American silver and the connection through the Philippines with America did more to open up these circuits, but they also had their own endogenous logic in many areas of Asia (Subrahmanyam 1990). The Indian Ocean and the Arabian Sea, from India to Madagascar, were replete with regional coastal circuits, many of 
them dating back to before the arrival of the Portuguese whose appearance in fact gave them a new dynamic. But, despite the connections with Portugal, the Asiatic economies had their own independence and a multitude of internal circuits. Today it is common to underline the fact that the portion of merchandise traded by the Portuguese-and, indeed, by the Europeans in general-was of reduced importance in relation to the total volume of traffic in these areas.

Globalization also implied the appearance of new routes. This was the case of the trade between Peru and the Río de la Plata (mentioned above) and that served to divert the route of the white metal that would not be channelled through the Carrera de Indias-and, therefore, that would not end up resting in the coffers of the King of Spain. It was also a zone whose base was smuggling, to which the Crown turned a blind eye, as we have seen. Moreover the Portuguese never came to control all of the commerce from Asia, as a significant part of it moved through the Red Sea and into the Ottoman Empire, thus creating another path of diffusion for these products. Carried through Greece and Venice, these goods often reached the north of Europe, usually passing through English hands (Fusaro 2015). The same effect was achieved by the inhospitable route that connected Persia with the north of Europe or travelled over Siberia towards the Baltic. The new commercial route between Acapulco and Manila strengthened these centrifugal commercial tendencies in the heart of the Luso-Spanish empire and, this way, increased the difficulties in controlling and maintaining the monopoly of Seville.

The impetus of both the regional economies, closely tied as they were to the expansion of international commerce, and the alternative routes of global trade can be interpreted as a symptom of the capacity of the world economy: it moved regional resources and generated new routes of economic development. It is also known that the fall in silver receipts in Seville and the crisis of Portuguese commerce with Asia would occur later than has been said. It certainly cannot be dated to before 1620-1630. But, on the other hand, it is also clear that these global mechanisms made it increasingly difficult to control the circulation of silver or maintain the extraction quota of the empire over a buoyant global economy that, even if it was in crisis in the short or long term, remained multipolar and with a very notable centrifugal component. As we shall see, this character would prove to be the Achilles heel of Madrid and of the empire. Would it also affect the economic agents who operated in it? 


\section{Problems of Regulation and Internal Conflicts}

Historians have recently proposed that these empires might be described as polycentric (Cardim et al. 2012). The expression adds little to what we already know but has an undoubted graphic value as long as we do not forget that some centres had less power than others and that Madrid was in many senses 'the' centre of the empire. It is important to underline, moreover, that all empires in history have been polycentric in many ways. Furthermore, one of the problems of the expression is that so far it has been applied mainly, or only, on the political and jurisdictional levels and that it suggests a certain sense of exceptionalism of the Iberian world.

This multinuclear character is, in realty, the fruit of the plurality of points of negotiation and, therefore, of decision-making centres that affected not only themselves but also the system as a whole. Nevertheless, from the perspective of political and institutional history, it is often forgotten that this nodal character became more evident with the development of regional economies and globalization. In effect the development of the regional economies implied the transferal to each of these centres of an opportunity to convert economic capital into political capital. The case of the development, almost fraudulent, of the Río de la Plata is paradigmatic, although perhaps in this respect the Philippines, Macao, or other areas might also be mentioned. In such centres, as economic resources increased, a number of agents emerged - that is, new elites and institutions that very shortly would negotiate with the Crown and, over time, would become decisive for the defence of the American empire as a whole. By 1630 there were many poles of regional development: in the Caribbean, Mexico, Peru, the Río de la Plata, Chile gradually, the coast of Brazil, the factories of Africa and the islands of the Atlantic, Lisbon, Madrid, Seville, Naples, Milan or the Low Countries, the coasts of the Indian Ocean, Goa, Macao, the China Sea, the Philippines, and so on. Furthermore, these were just the most important points, and under each of them were concentrated other, lower nodes of negotiation within the hierarchy. In each case we find a group in which a variety of agents negotiated with the king and among themselves. The case of New Spain provides a valuable example of the complex web of institutional relations at play. Here a range of actorsthe Consulate of Mexico, Mexico City itself, the freight shippers to the Philippines, the viceroy and the Audiencia - interacted among themselves, sometimes each pursuing its own agenda by recurring to institutional and 
economic privileges and yet, at the same time, also presenting claims for redress to the monarch in Madrid. Similar forms of rivalry and collaboration occurred under other types of institutional relations, for instance, in the European part of this composite monarchy (Chap. 5).

This situation ensued to the extent that the development of these new areas - and the deepening of the old ones-was based on the establishment of relations of do ut des with the Crown in which the concession of de facto jurisdictional or economic privileges played an essential role (these concessions and prerogatives came, nearly always, to assume a perpetual character); the system crystalized relations that were essential to its functioning. Still more important, privileges of this sort were seldom the fruit of a preconceived plan of imperial organization. On the contrary, these were relations borne of mutual necessity in specific conjectures between the king and local agents. And they responded to economic and political agendas marked by local concerns. The result was that the empire was configured as a group of different interests which were sometimes contradictory.

Many examples could be given. One study of the viceroyalties has arrived, with good reason, at the conclusion that 'jurisdictional conflict was the order of the day and formed part of the very nature of things' (Rivero 2011, p. 200). This author mentions another aspect of this situation, the collision of jurisdictions that formed part of the development of the European part of the composite monarchy of the Luso-Spanish empire. But the statement is also applicable to overseas territories, where institutions and an entire political philosophy had been exported and practices for the negotiation of privileges had been developed. For these reasons the Luso-Spanish complex existed during the first decades of the seventeenth century with a continual tension between placing more resources into the development of Pacific commerce - in which a large part of the Mexican and Lima elites were involved - and, alternatively, trying to limit and control it, as the businessmen of Seville and many who operated from Lisbon would have wanted and who saw in it a threat to their commerce with the Indian Ocean (Gasch 2015a). Even without resolving this question, the same phenomenon led to continual prohibitions being promulgated against the trade between Peru and New Spain that, if they appear not to have been entirely successful, did at least end the chances of uniting forces to proceed to the exploration and expansion into the South Pacific, a campaign that was left for English and French navigators (Céspedes 2009, p. 160). A similar conflict emerged over the development of trade through Buenos Aires, which infuriated the all-powerful Consulate of Seville, but 
was extremely remunerative for Peru's and the Río de la Plata's traders, as well as for the slave traders, many of them Portuguese, who connected this area with the Gulf of Guinea (Boyajian 1983; Studnicki-Gizbert 2007). The development of this route had strengthened the New Christians and Portuguese Jews who now, with the help of high-ranking governmental figures in Madrid, were coming into conflict with the Genoese over the control of the asientos (Ruiz Martín 1990b). Very similar conflicts were common in Asia. The opposition of institutions and Castilian and Portuguese corporations over China Sea commerce, or between enclaves such as Macao and Manila, and the disputes over the Moluccas, or over simple questions of naval protocol (and in this period, protocol was a means of setting the hierarchy of privileges that formed a part of political capital), are other good examples of this same tension (Valladares 2001, pp. 9, 20, 24, and 36). But, moreover, these conflicts could-and indeed did-have a markedly local character. Cases such as the dispute between the viceroy of New Spain and the bishop Palafox in Mexico have been considered as a clash of egos. But such episodes demonstrate a type of conflict between ecclesiastical power and civil authority that was present across the Iberian world (Álvarez de Toledo 2004). A good example can be found in the tensions between the Portuguese viceroy Linhares and the short-lived Portuguese East India Company, which decisively contributed to the failure of the latter (Disney 1978, chapter 9). Frontier zones, such as the region of Entre Rios in Argentina, were the stage for conflicts between the Jesuits and the governor of Buenos Aires for long periods of time (Ariel and Svriz 2016). Numerous other examples could be given (Herzog 2015).

It is important to note that tensions of this type - and forms of lobbyingare present in any polity, from nation state to regional government. What makes this a special case are the scale and nature of the problems of distance, asymmetric information, and monitoring difficulties. But all of these disputes, and many others of a more local character, expressed what was in reality a problem of regulation and arbitration that, if common to all empires, was inherent to the very model of development of the Spanish and Portuguese systems. As would happen centuries later to the British Empire, part of the problem originated in the difficulties in the very centre of the empire (Darwin 2012). If it was by this point difficult to coordinate missions in the peninsula and in Europe (Chap. 4), it was even more challenging to do so in the distant spaces in an empire marked by the difficult circulation of information and the high degree of autonomy wielded by local agents. In 1625 a well-informed expert on American society, Gaytán 
Torres, decided that the good government of the Indies required not only the purification of a thoroughly corrupt administration but also the reform of the various Councils in Madrid, whose rivalries and disputes were drawn out and debilitating (Amadori 2009). In the case of the Council of the Indies, clashes with the exchequer were especially frequent (Schäfer 2003, pp. 115-9 and 165-8). Joint actions involving the Council of Portugal and the Council of the Indies were not easy to coordinate. Moreover both councils (like all others) had more than one governmental function. As it has been said, they were also jurisdictional bodies and had to make sure that laws, customs, and rights (meaning therefore privileges) of each one of the components of the Iberian imperial complex were respected and upheld. And these were not always compatible. When Portuguese Jewish and Genoese bankers were in conflict, should the Crown back its traditional allies, who had mobilized the Republic of Genoa to serve the Habsburg cause of controlling Europe or its direct subjects from Portugal? In the majority of cases, when its own interest was at play, as was the case in debates about when or how it was to advance the exploration of the South Pacific that might well introduce even more centrifugal forces, the position of the Crown was to favour itself. But this, rather than correct the problem of regulation, only made things worse, and in fact it created a problem of arbitration from the centre.

\section{World War, Money, ANd Men}

These features of the Luso-Spanish composite empire were also present at its European extreme. Moreover, the problems of regulation in the Habsburg domains were not an anomaly in themselves. As we have underlined, they were the logical outcome of social and political development in tune with the epoch's political systems.

Problems would arise, however, when increasing pressure was put upon the different nodes of the empire in America, Asia, Africa, and Europe. Such pressure was not only the outcome of Dutch and English actions in Europe but also a side effect of the development of other areas of the planet in which globalization had also progressed since the sixteenth century. The climax of the increasing tension on a world scale can be seen in an event that has always been considered either in a strict European dimension or in its different parts separately: the Thirty Years War (1618-1648), or to be more precise the Eighty Years War, which started with the Dutch rebellion and ended with the Peace of Westphalia and the Treaty of the Pyrenees (1568-1648/1659). 


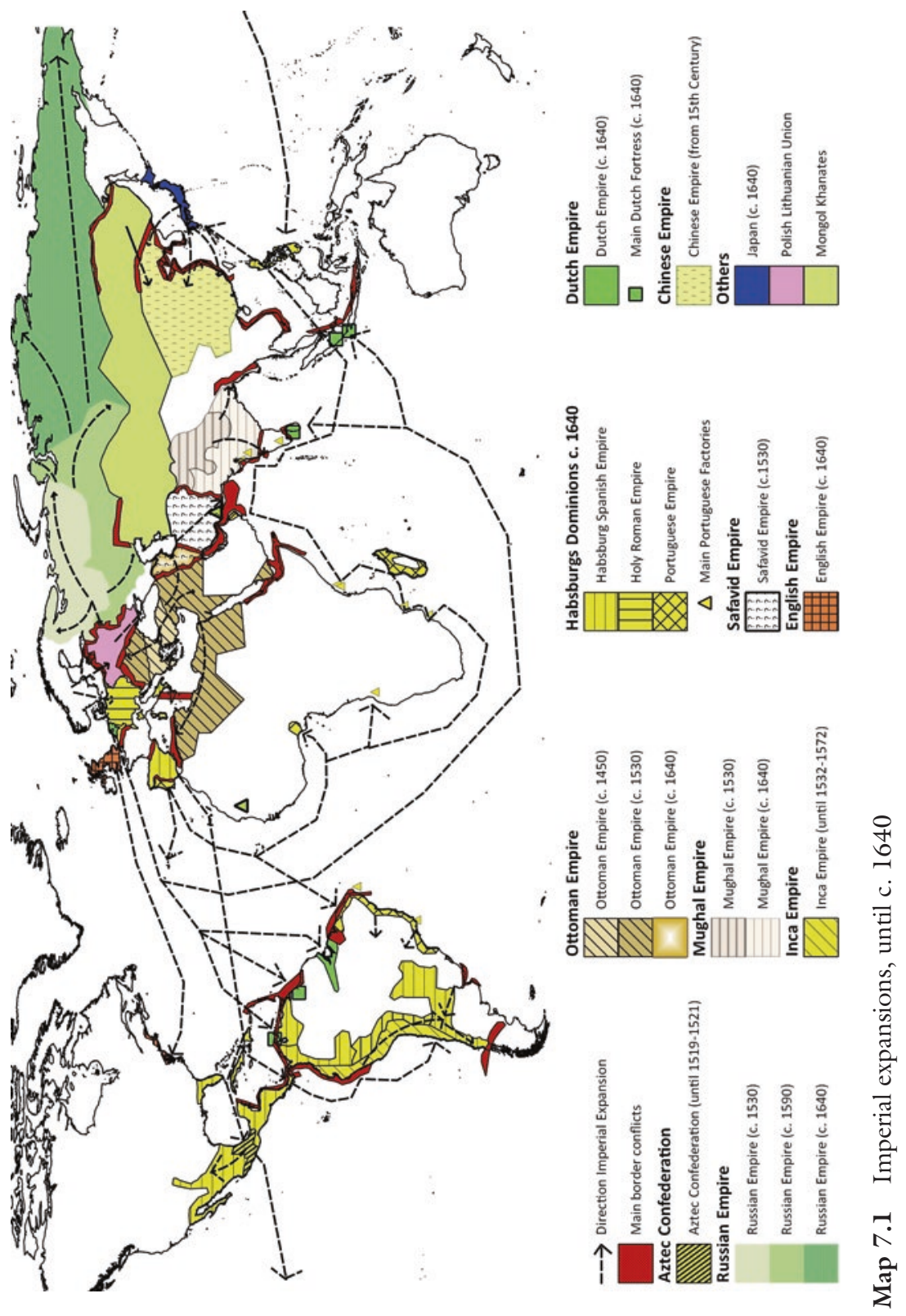




\section{Mars and Mercury on a World Scale}

The years 1598-1621 were decisive. Fighting on against Holland until 1609 created an exhausting situation for the royal finances. The reforming instincts of Philip III and his favourite, the duke of Lerma, are recognized today (Feros 2000). This having been said, patronage, clientelism, and political corruption, which cannot be separated from their economic context and which were a constitutive part of the political regime, originating in Lerma and his family, appear to have reached unprecedented level (Feros 2000, chapter 8). The patronage system, the spine of the political economy, developed to the extent that it became impossible to recruit the best-qualified servants to government through the client network (Williams 2006, p. 355). The dilemma between, on the one hand, clientele loyalty achieved through side payments that kept lineages united and softened their internal conflicts and, on the other, efficiency in political management was being decided too often in favour of the former. The situation was even more disturbing for many as not only had the millones tax been increased, but the minting of pellón coinage had been allowed, a measure that was considered by many thinkers, such as Juan de Mariana, to be an act of tyranny - a rupture of the implicit agreement between the monarchy and its subjects since 1469 (de Mariana 1987).

If they could not provide figures to substantiate their claims, contemporaries were very much aware of what was happening. This was especially true of the arbitristas, who flooded the Cortes and the desks of governors with proposals for reform and remedies (J. Vilar 1974; Gutiérrez Nieto 1982). If the solutions proffered were very diverse in nature, then their diagnosis of the problems remains extremely valuable in regard to their analysis of the political economy. According to the arbitristas, when compared to its European competitors, the Spanish economy had clearly run out of steam. The empire had fallen into a type of bad government that was being taken advantage of by other 'nations', among whose number figured not only the Dutch, French, or English but also-and above allthe Genoese, the Moriscos, and the gypsies. ${ }^{6}$ The Portuguese equivalent to the arbitrista literature, the so-called literature of remedies (la literatura de remedios), also dealt with similar topics and placed emphasis on the problems of the empire and of the Estado da India. The overall arguments

\footnotetext{
${ }^{6}$ See an example in Sancho de Moncada (1974 [1619]) and the introduction of Jean Vilar to his work (1974, pp. 78-81).
} 
were very similar, but they were exactly the same in their consideration of foreigners and, above all, in taking the union of the Crowns as one of the main problems of the empire and of the country (Curto 2009 and Borges 2014). It is precisely this negative impression of foreign influence that led to the fluorescence of a sense of Spain and Portugal as a dual political identity that would be the basis of subsequent reform projects infused with a clear mercantilist character.

In the case of Spain, among the reasons for this new feeling were the difficulties in overcoming the United Provinces of the Netherlands, with which a truce had been signed in 1609 .

By 1634 a painting was hung in the palace of the Buen Retiro in Madrid, which had been built for the greater glory of Philip IV (and, indirectly, for the Count Duke of Olivares). Its subject was an emblematic event: the recovery of Bahia in 1625. Laden with overt political symbolism (Brown and Elliott 1980, pp. 194-202), the work also appears today to reflect a number of elements that are crucial to understanding the political economy of the empire in these years: the likelihood of the Dutch attacking Portuguese areas of the empire, the fragility of Dutch efforts, and the considerable ability of the monarchy to react, despite its many problems. Without knowing it, the painting therefore confirmed the thinking of a group of Amsterdam merchants who, as we shall see, were increasingly convinced that the best way to penetrate the Luso-Spanish empire was by commercial infiltration rather than full frontal assault (Boxer 1973). Brimming with religious iconography and the representation of an imperial composite monarchy, the work of Juan Bautista Maíno perhaps demonstrates that the war with Holland was not a religious conflict. But neither was it a question of maintaining the unity of Habsburg patrimony; nor was it an economic war, despite its marked economic component, or one fought for reputation. Rather, it was all of these things at the same time. But, above all, this canvass allows us to understand that this was a global conflict fought by a geographically dispersed composite monarchy and dynastic world empire.

This unique combination of themes underlines the dilemmas of Spain when faced with its precise opposite, a small confederation of provinces: the Dutch Republic was a small and badly connected political system, an antistate (Elliott 1990); however, it drew strength from its spatial concentration and the high degree of interaction between its elites and government thanks to a system that permitted discussion and informal relations, in which conflict was often resolved with joint actions in defence of the 
economic bases of the country. It is not that corruption was inexistent in the Netherlands and even less the case that family networks were failing to penetrate its institutions in a similar way to what was occurring in Spain (Adams 2005). But its political skeleton was very different.

Any comparison between the Luso-Spanish empire and those that followed it, particularly the English and the Dutch, underlines this fact.

First, in contrast to the Iberian imperio, these were political formations in which the colonies were appendixes to proto-national states that comprised territorial unities and pursued a basically mercantilist agenda. In effect the great problem of the Spanish monarchy from 1598 to 1648, and more specifically from 1618 to 1648 , lay in waging war on a number of fronts across Europe from a mosaic of polities that were governed by a very wide range of political agendas, with very strong geopolitical constrictions and constitutions, whose interests did not always fall in line with those of the king. To this must be added that the dynastic nature of this ensemble created the duty of serving the general strategy of the House of Habsburg, manifested-it is only one example-in the participation in the Battle of the White Mountain (1620) in defence of the Austrian branch of the family and then sending help to repulse the attacks of Gustavus Adolphus of Sweden in Central Europe (from 1630). This role also created strategic problems that led to actions which were not only absurd but also enormously exhausting. This was the case in the attempted conquest of Mantua, undertaken to prevent the Nevers, a family tied to the French branch of the Gonzaga and therefore to Louis XIII of France, from seizing power in the duchy.

Second, such difficulties resulted from being a composite monarchy and empire. In an international war fought on various fronts, the obstacles created by the political theory, inherent to the composite, states to the transfer of funds from one state to another would pose a crucial problem. But this was also the case when it came to colonial areas and the need to use Portuguese and Castilian resources in a coordinated way. This difficulty became even worse to the extent that it coincided with the first globalization, which made the Iberian complex extremely alluring to maritime and commercial states such as Holland and England. In Europe, the problem was even more serious because of the pincers around France created by the semicircle of the Pyrenees, the routes of the Spanish road and Flanders, which obliged the neighbouring country to a continuous fight against Habsburg interests. 
Third, in many areas of the world, this was an empire of arteries and widespread neuralgic points. Its political and economic functioning depended upon a series of routes that tied together nuclei condemned to assist each other but whose local elites, bound by their separate and independent bargains with the Crown, found that their interests seldom coincided. For this reason, the geopolitical situation was implacable: the so-called Spanish road and the Mediterranean route from the East coast of the Iberian Peninsula was one of the most important but delicate routes, with an especially vulnerable point, the Valtellina pass in the Alps. The maritime connections between the Cantabrian coasts and the Low Countries were also vital. Along both routes men, military resources, and silver flowed, without which everything in the War of Flanders might have been lost. The connections between Lisbon and Brazil and their extension to the Río de la Plata were vital, as were the routes to Africa (where Guinea was also crucial) and the Indian-Pacific Ocean complex (in which Mombasa, Ormuz, Goa, Malacca, Manila, and Macao were stress points). Commerce was based in these sea lanes, as was the lion's share of Philip IV's income as King of Portugal and, most important, the loyalty of the Portuguese to Madrid. The other artery united Seville with the Caribbean, whence the fundamental routes to Mexico, Panama, and the coast of Tierra Firme ran; and in turn these points connected with the American Pacific and the links with the Philippines. Any enemy action against this artery threatened to interrupt the flow of silver to Castile, which in turn would endanger the financial nerve system of the empire. To give an idea of the distances involved, this network covered some 100,000 kilometres across oceans and along coastlines - two and a half-times the length of the equator.

Some of the fundamental characteristics of the Habsburg imperial system were, therefore, its dispersion and patrimonial nature, the obstacles to the mobilization of resources imposed by its character as a composite monarchy, and the strategic importance of some of the arteries and nodal points of the empire. Many empires have faced similar situations: their growth makes it more difficult to control frontiers faced with insupportable and continuous multilateral pressures, the variety of constitutions compels them to multilateral negotiations with local elites, military costs are always high, and so on. Indeed, some of these features have even been used to explain the failure of empires in general (Kennedy 1988). But the combination of all these characteristics in a moment of increasing globalization and fight for colonial markets would be decisive. 
In these circumstances, the strategy used by the Dutch and English was to focus on delicate points to assault or infiltrate, thus taking advantage of the problems in co-ordination and negotiation between local agents and Madrid, as well as the attendant logistical constraints.

A quick glance at events between 1580 and 1635 is highly significant. From the end of the previous decade, the English corsairs (Drake, Cavendish, and Hawkins) had attacked a number of points on the coast of Peru, California, Cadiz, and the Caribbean. The point of outbreak was always a neuralgic node for the transport of silver and the expanding plantation economy. At the same time, the Dutch had increased their presence in the Caribbean and the coasts of Brazil, being especially drawn by smuggling sugar and slaves. The powerful network of Portuguese New Christians would prove a great help to them in the moment of a boom in the plantation economy. But the Dutch intention was also to gain access to Peruvian silver, which they obtained by selling their goods in the New World and more in particular in the Caribbean and along the Northern coast of Brazil. The truce of 1609-1621 also allowed the Dutch to sell their industrial products directly to Brazil, while 'dozens of Dutch vessels sailed from Portugal to Holland' and carried merchandise in the other direction (Israel 1990, p. 117). Access to Peruvian silver through Brazil was getting ever closer. In the 1590s, at the very height of the war, the Dutch also began their own expansion towards the Orient. According to Headrick (2010, p. 87), they drew upon a number of advantages that allowed them to build fortresses in the 'Spice Islands', where they ran into the Spanish, who were based in the Philippines (Israel 1990, chapter 3), and Portuguese. By 1617 the Dutch had established around 20 strong port fortresses and were 'the strongest European power in Asia', having supplanted the Portuguese, even if then they also had to face the English (Israel 1990, pp. 104-106), whose penetration into Lisbon's empire was more subtle, if no less inexorable. These were also the years in which the English defeated the Portuguese at Surat (1612) and obtained trading privileges from the Great Mogul in return for providing protection to Muslim pilgrims (1618).

For these reasons, it is possible to understand why, when the truce lapsed in 1621, the prowar Spanish faction had in mind not only religious and dynastic ideals. Many people, and not only nobles such as the Count of Benavente, thought that Spain needed a 'good war' to avoid the country becoming effeminate and to satisfy the proto-national feeling surging within Castilian society (Elliott 1990, pp. 86-99). The Iberian merchant 
communities also saw Holland and, to a lesser extent, England as a threat that had to be faced down. But the Dutch strategy persisted. Despite the problems that it would cause Dutch trade, the war also provided the pretext for a new offensive, an important early move being the seizure of Bahia and infiltration into Portuguese commerce between Africa and the Brazilian plantations (Brown and Elliott 1980, p. 195), a crucial road for the Luso-Spanish trade networks. The capture of Recife (7 March 1630) and the control of the large Portuguese region of Pernambuco (1630-1654) had the same meaning (Boxer, 1973).

A replica of events at Bahia was the help of the English to the Sha of Persia to conquer Ormuz (1622), which allowed them to forge the land route to Aleppo thus connecting with the Mediterranean, as we have said. At the same time, the Dutch established their headquarters at Batavia (Yakarta), whence they organized their entire military and commercial system, even nurturing the idea of 'becoming a territorial power' by attracting huge numbers of Dutch colonists to it; this plan was never implemented (De Vries and Van der Woude 1997, p. 386). After 1630 English and Dutch incursions into the trade of the Luso-Spanish empire only grew. These years saw the Dutch position at Pernambuco gain vigour under the government of Joh Mauritius (Boxer 1973). In Asia they gained a foothold in trade between China and Japan, taking Formosa (Taiwan) in 1641 and expelling the Portuguese from Ceylon and Cochin (Kochi) in the 1650s.

It is to be noted, however, that the Iberian complex was not stressed only by European agents. Some of these attacks or resistances, and those in Asia in particular, were the outcome of the alliance between the Dutch and the English with the polities in the region. But, more important, the multipolar process of globalization (Chap. 1) was also behind the situation in the seventeenth century. By then Russian expansion to the East was reaching a crucial point. The Rurik and then the Romanov dynasties (1613) had created an empire with many similitudes to that of the Iberians, where the tsar negotiated power with the boyars in exchange for access to economic resources and labour (mainly based on serfdom) as well as with state servitors, who were rewarded with conquered and confiscated land (Darwin 2008, p. 73). By the 1640s the new Romanov dynasty dominated land from the Asian Pacific to the coasts of the Northern Sea and the Baltic. This reinforced the fur trade from Siberia and also the trade from the Eastern Mediterranean and the Black Sea with the north of Europe, thus connecting to the different branches of the Silk Road (Fusaro 2015). As we have seen, since the sixteenth century, the pressure of the other big 
agent of globalization in Eurasia, the Ottoman Empire, on the Indian Ocean increased, and it became even stronger after the Battle of Lepanto (1571). The English-Ottoman alliance in Ormuz was part of this process. The rise of the Mughal Empire during the sixteenth century and its expansion in India would be another important trend. After the Second Battle of Panipat (1556) and with the conquest of the Deccan since 1590s, the Mughal created a new and more centralized political formation, which would be more reluctant to establish alliances with the Portuguese, in part due to religious reasons, and keener to befriend the Dutch (Costa 2014, pp. 176-181; Flores 2015). Equally important are the development of Japan and the rise of the Tokugawa shogunate during the first decades of the seventeenth century. This more centralized political system was especially disposed against the religious interference of the Iberian missionaries and sought to weaken the trade they established with the daimios (Findlay and O'Rourke 2007, p. 172).

It is to be noted that these trends are associated with the rejection of religious interference from the West, as well as with the spread in Asia of European warfare technology. Again, globalization elicited negative responses to the Iberian power, which would find crucial points in its nodal scheme under increasing stress.

The period until the early 1630s cannot, however, be considered one of implacable defeat for the empires of Philip IV, which retained a considerable capacity for reaction. But the strategy to hit its Achilles heel (i.e. its nodal arteries) was already designed.

What was happening? Some time ago J. Elliott drew attention to the way that the English adapted and adopted the legacy of the Spanish empire (2006). In the same way, the Dutch and English were imitating the methods used by the Portuguese in Asia since the fifteenth century: the foundation of factories and emporia trade- of long tradition in this area even before the arrival of the Portuguese (Chaudhuri 1985, pp. 105 and 107) - the concentration of military force and commercial actions in strategic nodes, and the reduction of protection costs by balancing violence and negotiation on the local level. It is not the case that the Dutch did not try to conquer inland regions. The projects of Coen in Batavia (Israel 1989), where a vertical integration between spice production and trade led to the occupation of large territories, are good examples. The conquests of Bahia (1624) and then of Pernambuco (1630), with the intention of displacing the Portuguese from their continental dominium, are also a proof of this. But both campaigns showed that these were very risky 
and costly endeavours. The recovery of Bahia by the Spanish-Portuguese navy (1625) showed the inconsistency of this type of actions, and the fall of Pernambuco in 1654 was in part the consequence of the fact that in Amsterdam, 'the great merchant houses preferred an empire of trade and the expectations of quick profits to the uncertain and more distant returns from colonization' (Boxer 1957, p. 258)..$^{7}$ This preference was, however, as old as the hills and provides one of the keys to understand what was happening. Although the Dutch could have been making a virtue of necessity, from the early years of the seventeenth century, many Dutch businessmen were very clear that major campaigns of conquest against the Spanish should be avoided because they 'involved large, open-ended financial commitments' (De Vries and Van der Woude 1997, p. 386). Behind this preference is the idea that conquering extensive regions, and so having to meet the high inherent protection costs, would have compelled them to maintain an expensive bureaucratic apparatus and therefore to open negotiations with colonial elites on the basis of the Spanish model and transfer political capital to local powers, thus giving rise to massive levels of contraband and political problems. At least in this period-as perhaps today-it was easier to infiltrate an empire than build one.

But it is important to note that the Dutch and English were also taking a step forward in the history of the colonization of the world and in the relations between formal and informal institutions. The key here lay in the commercial companies. As public and private enterprises (Chap. 6), they created internal mechanisms for the regulation of conflicts between merchant interests and political concerns. K. Chaudhuri expressed this perfectly when he wrote that the VOC 'symbolised one of the most powerful and prestigious combinations of trade and political objectives that the commercial world of Asia had witnessed' (1985, p. 83). Of course quarrels and fraud permeated all aspects of the companies (Chaudhuri 1985). But their capacity to resolve tensions was in sharp relief with the difficulties in reconciling the interests of merchants and monarch in the Iberian world. Their mixed character - simultaneously public and private - and their ability to finance their own military apparatus allowed them to create long-term

\footnotetext{
${ }^{7}$ The opinion of Boxer remains all the more interesting to the extent that he placed special emphasis upon the human factor as a cause of the re-conquest of the island by the Portuguese. But his account also makes clear that the resistance of the Portuguese and Spanish moradores (residents) and the difficulties in obtaining logistical help were crucial to remove the powerful Dutch interlopers (Boxer 1957).
} 
strategies to resolve the classic economic dilemma of 'guns versus butter'. To be specific, in contrast to the Luso-Spanish empire, the Dutch were able to adapt and tailor their decisions in two senses: first, to delay the payment of dividends to their shareholders until their military power had allowed them to acquire and consolidate a solid position in the market (De Vries and Van der Woude 1997; Chaudhuri 1965) and second, and this was a crucial difference with the Luso-Spanish complex, to guarantee that the lion's share of available capital was used in costs that fed back into their own activities, something which emphatically did not happen with taxes paid by Iberian traders, an important part of which would end up in Flanders defending dynastic interests or, as Quevedo said, 'buried in Genoa', if not in the pockets of the bureaucrats, the aristocrats and what I have called the dominant coalition in general- let me add. ${ }^{8}$ In addition the companies, acting as cartels, were able to regulate their competition and to lower the prices of the products that they bought (Chaudhuri 1965), something equally unthinkable in a system as unregulated as that of the Iberian world, whose independent companies-based on the model of the Italian medieval compagnia - tended to have a very short lifespan and compete among themselves.

What was the impact of Dutch and English competition? Was it able to provoke an immediate decline in Luso-Spanish trade? The prevailing interpretation has been that from 1600 all of this was having a devastating impact upon Iberian commerce. This view is quite logical, as when things are examined from the Dutch or English perspective, the impression is of an inexorable rise of both powers (Israel 1990; Brenner 1993), and the perspective from Spain has always underlined the enormous problems of the Catholic monarchy and the deep depression that accompanied them. But this idea deserves to be nuanced in degree and chronology.

The official figures of this trade are very revealing. The number of sugar refineries in Brazil increased during the first decades of the seventeenth century at the same rate as the figures for the official exportation of this product (Mauro 1960). Something similar can be said of the dimensions of the Portuguese merchant fleet in this region, which grew without interruption between 1583 and 1629 (Costa 2002, p. 173). All indicators invite us to conclude that the trade in these products, as in others such as indigo and cochineal for which only the merest hints exist in the archives

\footnotetext{
${ }^{8}$ This is obvious in the Spanish side of the empire, but even more in the Portuguese dominions, as Boyajian has pointed out (1993).
} 
(Hough and Grier 2015, pp. 288-9), increased noticeably-or at least stabilized-during this period. A similar impression is conveyed by an analysis of maritime trade by the total tonnage of ships employed in the Carrera de Indias. Here a certain degree of Spanish resistance can be found, with figures remaining relatively high until the 1620s, with a notable fall occurring in this decade and a precipitous decline only in the 1630s and 1640s (Chaunu 1977, p. 255). This impression is corroborated by the evolution of the silver shipments arriving at Seville for private owners, a very important part of which were made up by consignments from emigrants and silver used to pay for merchandise sold in America (Bernal 1993). Figures for this sum, which provide a good reflection of the official commerce of Seville with America, reached their maximum proportions between 1616 and 1630 for the entire period 1500-1650. ${ }^{9}$ If we add to this sum the value of the goods that came in these shipments, most of which was the fruit of colonial commerce (Bernal 1993), the impression is even more positive. And this is even more the case if the noticeable expansion of the commerce carried by the Manila galleon is taken into account, with the massive arrival of products from Asia in New Spain and a considerable reverse flow of silver (TePaske 1983, Gasch 2012). None of this can be considered strange if the upward cycle of silver production in the first decades of the century is added into the equation (Bakewell 1991); nor should it be forgotten that these years witnessed a marked expansion of the urban economy as well as the plantation economy and the linking together of economic networks in Latin America (Carmagnani 2011).

The same impression is given if we analyse the figures presented by Duncan some time ago for Portuguese trade in Asia (1986). Arrivals in Lisbon, as in Asia, without doubt the most reliable variable of the rhythm of commerce, remained high until 1620 and the more dramatic fall did not take place until 1630. Such a conclusion is reinforced by Boyajian's analysis, according to which private trade, particularly in the routes to Asia but also those to the Cape of Good Hope, 'did not collapse with the advent of European competition in Asia in 1600' and was in fact in its

\footnotetext{
${ }^{9}$ Using Hamilton's figures as a basis, I have calculated that these proportions constituted $85.5 \%$ between 1616 and $1620,81 \%$ between 1621 and 1625 , and $81 \%$ between 1626 and 1630; while in the overall period 1580 to 1650 , only on one occasion, 1646 to 1650 , did it reach the figure of $85 \%$ (and figures for this period are highly uncertain). In general the figure had moved between 60 and 75\% (see Hamilton 1975, table on p. 47).
} 
zenith during the two first decades of the seventeenth century (1993, p. 241).

But what lies behind these figures?

It is worthwhile underlining that the infiltration of foreign businessmen and products into this commerce was highly important in the centres around which all else turned, Seville and Lisbon.

Contrary to the image of the Carrera de Indias as a monopoly system for the control of trade, it is to be noted that Seville was the main loading point for the shipping of non-Iberian products. The Crown's cession of the right to register products carried to America to the city's Consulate in return for sworn declarations of their worth and then, later, for fixed fiscal evaluations of the value of the contents of the shipments (see Chap. 5 above) was having its effects. This process continued during the seventeenth century. In return for a gift to the Crown (donativo) of 200,000 pesos (see below), in 1629 the system was changed to that of avalú, in which tax assessment was made according to the weight of the crates and not the value of their content, a good deal of it being composed of highvalue low-weight commodities. ${ }^{10}$

All of this acted in combination with the very system of financing the Carrera de Indias. Seville trade was predominantly based upon the 'loan at risk' (préstamo a riesgo) in which the lender, who assumed the risk, advanced money to a borrower who would repay the loan in America once he had sold his merchandise. Given that this restitution was made by an exchange of money between Spain and America and that considerable risk was involved in it, the interest rates of these loans were very high (normally between 80 and $100 \%$ ). This meant that only the great merchants could undertake operations involving very large shipments and that, frequently, the loan consisted in the handing over of merchandise whose value, plus interest payments, would have to be returned to Seville after its sale in the colonies. For this reason this system ended up favouring operations among the great international merchants (inserted in networks with their epicentres in the Low Countries, England, Italy, etc.), who took advantage of Castilian front companies with presence in the Consulate to insert their products in America, using the main artery of this trade. This

${ }^{10}$ This is in itself a persuasive reason for thinking that figures produced by Hamilton and Chaunu should always be assumed to be lower than the real ones, as they referred in most cases to shipments of high-value fabrics. 
was an authentic example of 'legalized contraband', which allows us to understand why, despite the figures on commerce remaining relatively high until the 1620s, their positive effects on the Spanish economy in general and its industry were less than could be expected. The system was aggravated-and this was the accusation of the Seville shipping merchants-by the presence in their city of the so-called peruleros, Peruvian traders who operated in the zone and who, after the foundation of the Consulate of Lima (1613), were able to defend their interests more effectively before the Crown. Their arrangement consisted of obtaining loans from private individuals in America and, having transferred the monies to Seville, the purchase in big quantities of products that would then be shipped back across the Atlantic (Oliva 2004, p. 36). The advantages acquired over the previous decades by the industries of the north of Europe, the lower prices of goods from these areas, and the strength of the foreign wholesale traders made them especially competitive in the markets of Seville and America.

It is interesting to underline some notable parallels with changes in Portuguese commerce. In contrast to the Castilian model, this was not a royal estanco ceded to national merchants, in which most royal income came from taxes paid on commercial activity and the taxes in America and mining activities. In Portugal it was the Crown itself that retained its rights to trade. But, in any case, the system of licences - which, as we have seen, proliferated from the end of the sixteenth century-implied that the Portuguese king's ships would be loaded by non-Portuguese merchants and that, by extension, the majority of the profits would not remain in the country or have a small positive impact on the sectors that might have created added value (Godinho 1982).

It is therefore evident that colonial trade from Seville and Lisbon remained very dynamic but also that part of it was already in the hands of transnational merchant networks.

Important as the infiltration of foreign merchants in the ports of both Seville and Lisbon was, evidence also suggests that direct smuggling between other countries and the colonies under Portuguese-Spanish control was also increasing and would gain momentum from the mid-1620s. To justify this assertion for the Asia trade, one can recur to a comparison between the ships arriving at Lisbon and Holland from Asia (Graph 7.1). But the fact is also obvious in the increasing losses of Portuguese ships-in a good deal due to Dutch and English attacks_-during this period, as well as in the way 'the private traders conducted by royal officials, soldiers and 


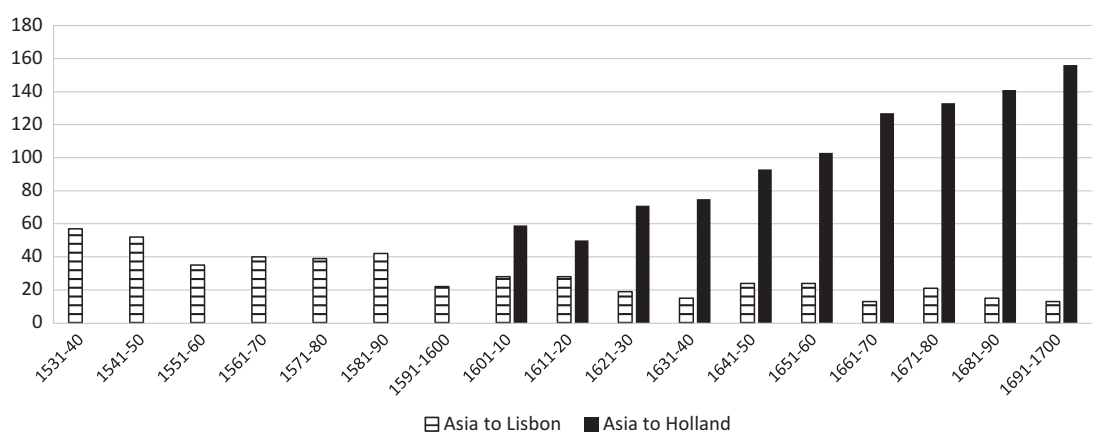

Graph 7.1 Ships arriving from Asia to Lisbon and Holland Sources: My own elaboration with data from Israel (1989) and Duncan (1986).

private merchants' undercut the Crown's exclusive control of this trade (Schwartz 2007, pp. 27-28). Something similar can be said of American trade, if we take into account the marked increase in freight prices in traffic to Brazil, a variable that was also partly influenced by the security of commerce. ${ }^{11}$ The importance of smuggling, and the redirection of the trade at the expense of traffic in the Carrera de Indias between Seville and the Caribbean, is also clear in research on the Río de la Plata. ${ }^{12}$ There is also the suspicion of a growing Dutch presence in the area, allowing more effective contraband from the 1620s onwards, something which is corroborated by qualitative data.

In conclusion, the most probable explanation of what was happening is that between 1580/1590 and 1630, America witnessed very marked growth, thanks to the coincidence of the last cycle of mining and an explosive burst forward of the export-orientated plantation economy. ${ }^{13}$ Rates of urbanization, if rather crude and not directly dependent upon the development of plantations, endorse this view too. Similar deductions can be made from quite a few qualitative indicators. Thus, the strong growth of

\footnotetext{
${ }^{11}$ According to the figures of Leonor Freire Costa (2002, pp. 76-7), it is clear that costs grew between 1580 and 1600, before stabilizing and even falling during the truce of 1609-1621. After this point they shot upwards.

${ }^{12}$ Moutoukias' study presents its most consistent figures for the period 1650-1700, but his data also underlines the dynamism of the early decades of the century in the formation of the Peru-Buenos Aires smuggling axis (Moutoukias 1988, Chapter 2).

${ }^{13}$ The growing number of slaves carried to the New World supports this analysis (Engerman and Genovese 1975; Curtin 1969).
} 
the American economy was able to sustain expanding trade within the New World and also an increasing official and contraband trade towards other continents at the same time until 1630. Something similar must have been happening in Asia, where Europeans as a whole were diverting towards the west a growing proportion of the local and interregional trade that, as Subrahmanyan says, was very voluminous and therefore allowed them to redirect greater quantities towards the old continent without suffering adverse effects.

From 1625 to 1630 , the advance of Holland and England would be even clearer, and by 1648, when peace was finally signed with Holland, the system had reached a dramatic and ironic perfection. The policy of striking against weak points and infiltrating the trade of Lisbon, Seville, and other peripheral areas of the empire was yielding results. In both cities, the so-called monopolio now benefited many other countries. Moreover, smuggling was practised from strategic points in the Caribbean, Africa, and Asia. This situation was even more dramatically ironic if we take into account that the Catholic monarchy was seeing its spending rise for both the protection of these empires and the preservation of their markets (see below). Mercantilism was not only impossible but also benefited foreigners in proportion to the efforts to apply it. The outsiders had now found their 'Indies', as Thomas Mun would say in a work published posthumously in 1664 (Chap. 6). They had first imitated and then adapted the Portuguese techniques, at the same time as they learnt from the errors of the Spanish colonial system. Mun himself, as a director of the English East India Company, had been one of the protagonists in copying and perfecting existing practices and well knew the high cost that alternative experiments might entail. The Dutch and English were able to continue to trade in many American zones without having to take the trouble of conquest, thus saving themselves costs associated with social control, coercion, and administration.

Around 1620 Seville was brimming full with Flemish merchants and merchandise; representatives of other northern nations and Italians were equally prominent. The rise of the American market was now beginning to have a very positive effect on the industries of different areas of Europe, all of them more competitive than Castile. The English had gained access to the Mediterranean, and their 'new draperies'-light, fashionable, and adapted to the climates of the South-were starting to be worn by a good deal of the urban population both in the Iberian Peninsula and in the colonies (Brenner 1993; Coleman 1977). The Dutch, thanks to their multidirectional growth and expanding global markets (Israel 1989), were 
establishing a centre of information and exchange whose tentacles reached into every part of the world economy and through which data and intelligence were gathered, costs lowered, and predictions made as never before. Economic development and political independence-achieved through military efforts-meant that the Dutch hub was much more efficient than Antwerp had ever been (De Vries and Van der Woude 1997, p. 667). The French were a growing presence in Spanish and American trade and were setting down the basis for a system that would reach its full maturity and potential in the second half of the century. All of this was achieved at a time in which the presence of Italian industrial products in the international markets was declining, as these were now hindered by diminishing competitiveness in terms of their cost and capacity to adapt to market demands, as well as the inability of Italian political systems to exert influence successfully in a world increasingly shaped by mercantilist considerations and policies.

\section{Global Wars and the Relevance of the Imperial Periphery}

The traditional view of what was to occur is quite clear. The decline in American revenues, traditionally associated with the mining crisis, reduced the Crown's income precisely when the domestic economy was weakened and the Thirty Years War, understood as a European conflict with some colonial extensions, reached its climax. Under such circumstances, Castile would remain the only territory disposed to endure the conflict's enormous burden. ${ }^{14}$ However, if a wider global perspective is adopted to analyse this period, the final impression may be very different. Any such attempt may even cast a great deal of light on processes that reshaped the empire and were essential in the long term.

\section{Cash for the King on a Global Scale}

It might be said that we are dealing here with an economy of war in many senses. This is evident in the fact that military spending, and the payment of debts contracted to meet it, by themselves constituted more than $60 \%$ of Castile's ordinary expenditures. ${ }^{15}$ This stress provoked by war is also

\footnotetext{
${ }^{14}$ A number of excellent studies can be consulted, in particular Domínguez 1983, Ruiz Martín 1990b, and Gelabert 1997, 2001.

${ }^{15}$ By 1598 spending in Flanders and in general defence rose to 3.45 and 3.4 million ducats, respectively, more than $50 \%$ of total governmental expenditure as a whole, and in 1621
} 
evident in the subscription of both asientos and juros and paved the way for the bankruptcies of 1607, 1627, and 1647 (Gelabert 1997; and Ruiz Martín 1990b). ${ }^{16}$ The problems accumulated after 1580 with a cessation of growth in the interior zones of the Meseta and the end of expansion in Andalusia, the most highly taxed areas of the Crown, had a deleterious effect (Castillo 1965). Due to the limitations of what we have called the conflictive pact, the fiscal system was reaching the limits of its efficiency: clientelism, corruption in local and central management, disorder in the collection of taxes, and many other deficiencies were now becoming a problem (Domínguez 1983).

In this context, the war economy would reach its fullest extension. In the first decades of the century, the sale of baldios and common lands had continued, as had those of jurisdictions and royal rents, reinforcing tax pressure upon the remaining royal domain. And if the alcabalas were hardly increased, these had now to be paid in some areas that contained a decreasing number of persons. ${ }^{17}$ The outbreak of war in 1621 made things even worse. The decade would be marked by the negative effects of the minting of vellón coins, which brought about a rise of more than $40 \%$ in the premium of silver money in just eight years. ${ }^{18}$ International payments (above all those effected in Flanders) could only be made in gold or silver: the result was a drastic reduction in the capacity of the monarchy to attend to the international dimensions of the war (Parker 1972, 247-65). These effects were even more prejudicial since between 1600 and 1640, the guil-

they reached 3.1 and 2.9 million, respectively, equivalent to half of the total. Moreover the second most important part of governmental spending concerned the servicing of debts, most of which derived from military spending. Payments on juros alone constituted 5.6 million in 1621 , that is, $40 \%$ of the total cost and more than $50 \%$ of the income in this year (Thompson 1976, p. 288).

${ }^{16}$ The evolution of the asientos is indicative in this regard. They increased between 1602 and 1605, before falling, doubtless because of the bankruptcy caused in 1607. From around (approximately) 1616, a new growth cycle began, reaching a peak for the reign in 1623-1625, with the bankruptcy of 1627 on the horizon, after which a new dip can be seen. The war of Mantua, and specifically the entrance of France into the conflict, brought about a dramatic increase, which lasted until 1642 (Gelabert 1997, Graph 1.1, p. 323).

${ }^{17}$ In Segovia the alcabalas hardly rose between the 1570 s and 1620 s. But this quantity had to be paid by a population that had fallen by almost $25 \%$ and which now also had to pay the millones and other burdens (García Sanz 1987).

${ }^{18}$ It has been calculated that this led to an appreciation of up to $120 \%$ by 1648 as a result of the repeated minting of new vellón coin, with another royal bankruptcy in 1647 (Hamilton 1975, pp. 105-12). 


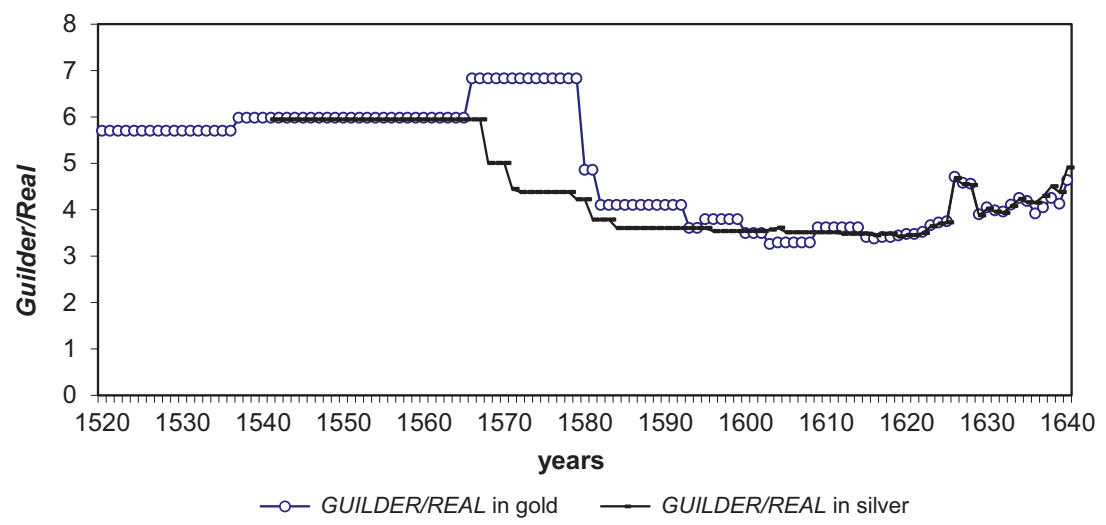

Graph 7.2 Guilder/Real ratio in gold and silver Sources: Posthumus (1946, Tables VI to VIII) Feliu (1991, Table II.1), Hamilton (1975; p. 85, Table 4) and Yun (2004). For more details see Yun (2004; p. 142).

der rose in value by more than $30 \%$ in relation to the silver real (Graph 7.2). And from the 1630s, new payments of the millones taxes were introduced, their value quadrupling in many areas (Artola 1982). But, above all, this situation led the government to the arbitrios, or extraordinary measures, which on many occasions were not negotiated in the Cortes.

The complex constructed by Charles $\mathrm{V}$ was thus trembling (see our description in Chap. 4). The fiscal pact between the Cortes of Castile and the king was now weakened; the system for the consolidation of debt was taking on water like a sinking ship, and would continue to do so to the extent that the dynamism of the economy was falling. This was all the more evident since the other fundamental pillar, the royal American revenues, was also now cracking. The royal silver shipments, which had begun to fall in 1600, reached a level in 1616-1620 that did not exceed that of 1566-1570, when the Seville boom in metals began (Hamilton 1975, p. 48). Thus, the lubricant that served to obtain asientos and then to consolidate them as juros on Castilian incomes fell short. This would have very prejudicial effects, not only for the phenomenon in itself but also because it struck a blow to a fiscal system that was by now very highly 
indebted. ${ }^{19}$ Even the other pillar, the credit provided by the Genoese, now began to weaken as did the difficult and fragile alliance with them. The bankruptcy of 1627 made it clear to Olivares and, indeed, to everyone else that now was the time to replace the Genoese or at least to counterbalance their enormous power (Boyajian 1983; Ruiz Martín 1990b). A policy of approximation to Portuguese Jewish bankers and conversos was therefore introduced. If the final result was not the credit monopoly falling into the latter's hands, then it did, over the century, produce a greater number and range of asentistas and agents, to whom the monarchy was much more closely tied for reasons of international political strategy (Sanz 1988).

But what was the real role of the colonies in this situation? Can we reduce the problem to a crisis of the Crown's colonial revenues, meaning a reduction of Asia's and America's capacity for sending money to the peninsula? Nothing could be further from the truth, although this interpretation has predominated when the problem has been viewed from a strictly peninsular perspective.

Certainly, the Portuguese system was facing difficulties. Here smuggling and the growing Dutch presence in Asia were bringing about a financial crisis in overseas incomes. But the other big problem was in the licence system, that is, in the fact that a big proportion of the colonial benefits were going to private hands, especially those of transnational and global agents. The kings of Portugal were seeing a fall in their income for this reason from 1588; by 1627 they hardly garnered a quarter of what they had at the beginning of the period, a sum that practically disappeared between 1632 and 1641 (Hespanha 1993b, pp. 197-205). Furthermore, as in Castile, a phase of sharp inflation in the 1630s eroded the buying power of the tax intake (Hespanha 1989, p. 112). Once again, the problem was the stress experienced by a global system that had functioned relatively well during the sixteenth century but that generated insuperable tensions not only at its centre, as is normally said, but, more important, on its periphery.

But the case of Castile is more meaningful. As we can see (Graph 7.3 and Table 7.1), the decade 1601-1610 saw a fall in the shipments of silver reaching the king from America that would continue until the 1640s,

\footnotetext{
${ }^{19}$ If in 1598 the juros absorbed approximately $45 \%$ of Crown incomes (4.6 million ducats from 10.22 ), in 1621 it had already reached $60 \%$ (5.6 million from 10.52 ). This is all the more revealing in that these years had seen a fall in the interest rate on debt from $7.1 \%$ to $5 \%$, and many juros had been pledged by the Crown as security on these lower levels.
} 


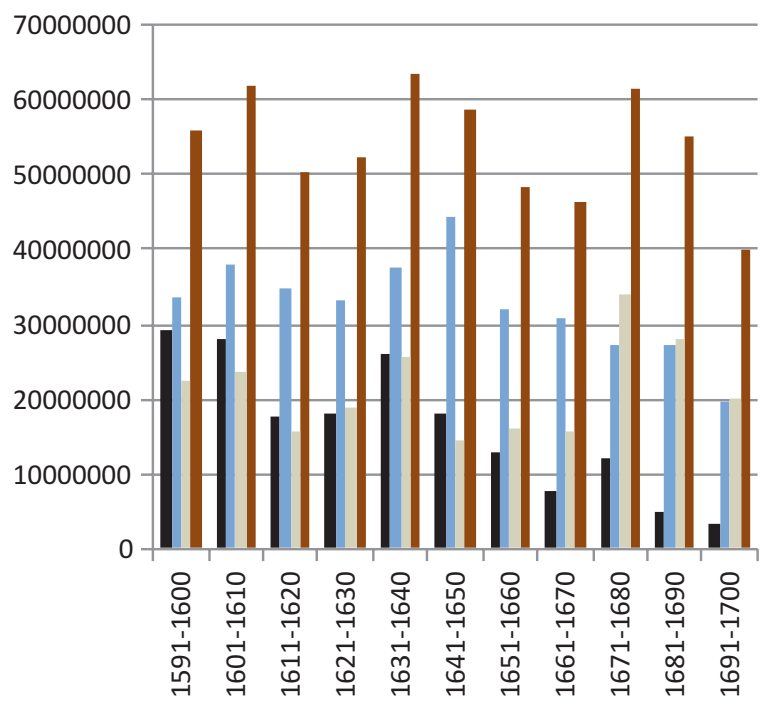

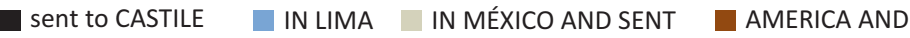 TO PHILIPPINES PHILIPPINES

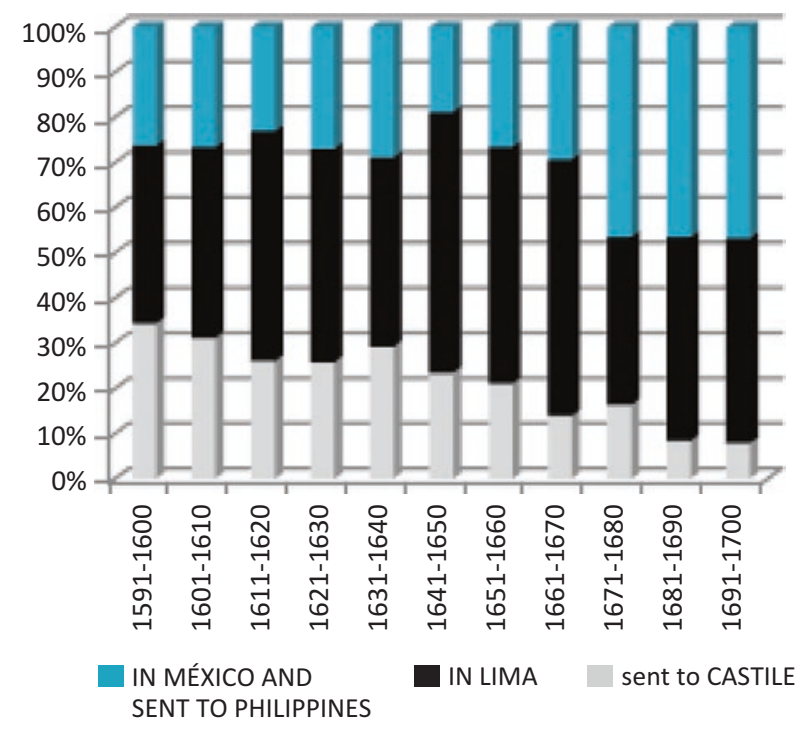

Graph 7.3 The distribution of the Spanish Crown American income Sources: My own elaboration with data from TePaske and Klein (1982, Appendix). 
Table 7.1 The distribution of the American Income (Spain)

\begin{tabular}{lrcccc}
\hline & Sent to Castile & In Lima & $\begin{array}{c}\text { In México and } \\
\text { sent to Philippines }\end{array}$ & $\begin{array}{c}\text { America and } \\
\text { Philippines }\end{array}$ & $\begin{array}{c}\% \text { sent to } \\
\text { Castile }\end{array}$ \\
\hline $1591-1600$ & $29,290,549$ & $33,683,302$ & $22,270,657$ & $55,953,959$ & 52.35 \\
$1601-1610$ & $27,960,747$ & $38,006,115$ & $23,772,246$ & $61,778,361$ & 45.26 \\
$1611-1620$ & $17,816,355$ & $34,664,082$ & $15,720,600$ & $50,384,682$ & 35.36 \\
$1621-1630$ & $18,159,998$ & $33,319,795$ & $18,939,319$ & $52,259,114$ & 34.75 \\
$1631-1640$ & $26,217,176$ & $37,686,150$ & $25,844,488$ & $63,530,638$ & 41.27 \\
$1641-1650$ & $17,937,904$ & $44,162,913$ & $14,411,753$ & $58,574,666$ & 30.62 \\
$1651-1660$ & $12,912,496$ & $32,077,933$ & $16,182,019$ & $48,259,952$ & 26.76 \\
$1661-1670$ & $7,559,713$ & $30,655,309$ & $15,796,262$ & $46,451,571$ & 16.27 \\
$1671-1680$ & $12,056,228$ & $27,249,881$ & $34,104,600$ & $61,354,481$ & 19.65 \\
$1681-1690$ & $5,078,377$ & $27,166,234$ & $28,013,250$ & $55,179,484$ & 9.20 \\
$1691-1700$ & $3,422,516$ & $19,606,978$ & $20,199,095$ & $39,806,073$ & 8.60 \\
\hline
\end{tabular}

Sources: TePaske and Klein (1982, Appendix)

when a definitive collapse occurred. In these conditions it was extremely difficult to meet the needs created by the renewal of war in 1621 (Lynch 1969, pp. 71-6).

But, more than a crisis in the colonial tax system, what in reality was taking place in the long run was a downward trend in the proportion of the silver brought to Castile, with more remaining on the empire's periphery. Thus, if $64 \%$ of income in Lima were sent to Spain in 1591-1600, this proportion fell to $45 \%$ in 1601-1610 and 'to about one third for the next two decades'. In the 1670s it hovered around $8 \%$, and in the following decade, it had fallen to $1 \%$ (TePaske 1983, pp. 427-8). This tendency was repeated in Mexico, which moved from sending around $90 \%$ to Spain between 1581 and 1610 to almost $60 \%$ in $1641-1650$. The remainder either stayed in America or was employed in the Philippines (being directed above all to defence, as we have seen) (TePaske 1983, Table 4, p. 444). These facts have even greater relevance given that in New Spain, in difference to Peru, mine production and, therefore, the incomes derived from it appear not to have diminished. Table 7.1 which represents the total income in America and the proportion sent to Castile is very meaningful. The total income fluctuated until 1680-1691 and only decreased in a very substantial way in the last decade of the century. But the proportion sent to Castile dramatically decreased during the century and more in particular after the big effort of 1631-1640, with the entry of France in the Thirty Years War. 
There are a number of reasons for this, but one above all must be underlined: growing proportions of metal remained in the colonies to meet their own needs and above all the defensive costs that were rising in response to the Dutch and English attacks. Thus, one of the reasons for the growing military problems in Europe was the global character of the war and empire. In broader terms, the difficulty lay in the growing needs of a global empire that had to establish and defend a multitude of local interests and centrifugal forces spread across a vast geographical area and whose local elites demanded that the empire attend to their protection costs by spending a growing proportion of their taxes. It is important to note too that, if the silver collected in America remained at very high levels until 1681-1690, all available figures on mining production indicate an unbroken fall that began from 1620 to 1625 and continued until 1660-1670 (Barrett 1990, Figure 7.1, p. 238). In other words, a sizeable part of the shortfall was now coming not from the mines but from the pockets of the American population. It is not odd, therefore, that bigger parts of the budget were contributing to maintain the defensive system and the American colonial administration.

It should be noted that this is not only the case of America. In a revisionist study published years ago by Storrs (2006), this author made clear that the effort of the Habsburg empire's non-Castilian territories of Europe also increased during the last 30 years of the century. But this can be said also for the previous decades, in spite of the Union of Arms' failure. Thus royal incomes in Naples rose from some three million to almost six million ducats between 1600 and 1640, a 100\% growth in nominal terms. This in fact meant a considerably larger contribution in real terms, since the fall of prices in the kingdom after 1620 also brought about a reassessment of the taxes levied, thus increasing the overall contribution of this state in real terms. In this kingdom, the consolidated debt grew by 65\% between 1605 and 1638 (Calabria 1991, p. 91). ${ }^{20}$ Something similar occurred in the territories of the Crown of Aragon, although on a somewhat lower scale (Bernabé 1993). Catalonia had already increased its extraordinary tax payments in 1599 up to $1,100,000$ lliures a year (Elliott 1963). But, very importantly, in all of these kingdoms, new taxes were created on productive activities and commerce. These payments entailed

\footnotetext{
${ }^{20}$ According to figures presented by Calabria, the Crown incomes in 1638 were about 5.6 million ducats, whereas the public debt came to 3.2 million (1991, Appendix I, Tables 1 and 6, pp. 134 and 142).
} 
contributions to the war or support for military units in situ. And, as in Castile, the municipalities had to impose sisas (sales taxes on items weighed or measured) to meet the costs of war (Bernabé 1993). ${ }^{21}$ It is very difficult to work out the monetary contribution of the Low Countries. These monies remained in the treasury of the army, which in any case appears to have acted as an extractive mechanism, and when taxes were raised by local authorities, they proved barely sufficient to cover the cost of their own defence. But G. Parker has calculated that from 1600 to 1640, the 'obedient provinces' contributed some 4,000,000 florins a year (almost three million ducats) (Parker 1972, 144). ${ }^{22}$ In Milan the system of contributions by compensation (compensazione) and levelling off (egualanze) for the maintenance of troops was equally indicative of how war and the overall military system of this composite monarchy generated costs and how its 'peripheral states' were obliged to increase their incomes, as well as their contribution to warfare. ${ }^{23}$

\section{But Not Only Cash: The Real Burden of the War}

The contribution of the periphery of the monarchy to the imperial efforts on its many battle fronts is even clearer when the focus of attention moves from money to men. In effect, the economy of war was characterized by the use of forms of resource extraction that, in addition to taxes, resulted in the direct mobilization of troops and military units on the local level and battlefield. This is important in this case, since, as has been said in Chap. 4, the fiscal system is too often confused with the system for the mobilization of resources sensu lato. Yet this consideration is crucial to understanding the impact of war on the empire and not only-or so

\footnotetext{
${ }^{21}$ The viceroys of the Principality of Catalonia were able to extract more from towns, with Cervera's contribution rising from 5500 to 23,000 lliures between 1611 and 1618 (Elliott 1963 , p. 145).

${ }^{22}$ This is, perhaps, an exaggerated figure. In fact, it comes close to the contribution of Castile itself to the war, if we follow the figures of Thompson (1976, p. 288). But other calculations hold that Flanders provided $25 \%$ of the resources for the war, which is at least one-third as much as Castile and not negligible (Esteban 2002, pp. 62-3). This makes sense if we add to the figures for 'Flanders' given by Thompson those relating to 'defence', some three million ducats in 1621 .

${ }^{23}$ Buono (2008, pp. 35-48). The author describes 'compensation' as the right of local inhabitants to be compensated for the real cost, including the destruction of property, the lodging and keep of troops; in this arrangement zones that had not seen active fighting or billeting contributed to the costs of those that had.
} 
much-because of its weight but also because of its footprint on the political economy.

As expected, this type of contribution was very much present in Castile. Continuing the tradition set up in the precedent century, many cities-for example, Seville, Mérida, Segovia, Salamanca, and the coastal ones-came to contribute in this way with armies which were sometimes better paid than those of the king himself (Thompson 1976, pp. 134-5). There are some reasons to believe-though no overall figures can be provided-that efforts of this sort were extended in the 1630s, above all because of the war with France, which threatened the very Spanish territories (Mackay 1999, pp. 80-96). Thompson puts the value of the salaries and military equipment given by Seville at some 170,000 ducats during these years. In Murcia, the most exhaustively studied region, the city paid for armed men at its own cost and maintained its walls. It was also involved in skirmishes on the coast of Africa and even contributed to the maintenance costs of Orán (Ruiz Ibáñez 1995, pp. 227-9 and chapter VI.3). By the same standard, the city of Cartagena was directly involved in privateering offensive and defensive activities organized from its harbour (Ruiz Ibáñez and Montojo 1998).

Also like in the preceding century, this was not only a business of towns. Nobles were actively involved in raising men as a form of service paid for from their own pockets (or by advancing money). Troops of this kind were, at heart, a form of 'tribute in kind' rather than in liquid money, although at times this sort of contribution might be commuted for payment in metallic (Mackay 1999). ${ }^{24}$ Thompson has argued that the fact that the treasury receipts of Philip IV did not exceed those of his grandfather 'is an indication not that the costs of government had remained unchanged, but that the central administration was now taking a smaller share in the management of the state' (1976, p. 141). In other words, the treasury figures do not provide us with the full picture, as has often been assumed. Moreover, all of these political actors contributed to the mobilization of troops, as was normal in a corporate composite monarchy.

But, as with the flows in cash, the contribution of other kingdoms was not negligible at all. The case of Milan, just mentioned, is perhaps one of the most expressive (Maffi 2009), as long as the compensations were

\footnotetext{
${ }^{24} \mathrm{~A}$ meaningful evidence is that of the total number of censos taken out by a wide section of estates belonging to the titled nobility between 1580 and 1640, 18\% were for military services (Yun 2002a, p. 175).
} 
associated with military mobilizations in situ, which opened the door to possible excesses related to the transfer of nonfiscal resources to the central power from the areas affected by the presence of troops. Moreover the levies of soldiers, their billeting, the forced purchase of provisions, and other actions, constituted a compulsory contribution that cannot be calculated but which should not be hidden behind the figures derived from treasury and exchequer accounts (Buono 2008). To the body of 60,000 men under arms, all paid for by the Crown, can be added the urban militias supported by the cities. This mechanism for the mobilization of resources, which often did not leave records in the central treasuries, was also employed in Sicily and Naples (Rizzo 1995, and Muto 2007). Though sometimes mixed with flows of cash, it also proved very common in the battlefield of the Low Countries (Parker 1972). We also know that local levies were raised in the Crown of Aragon, sometimes even as a result of forced agreements conceded by the Cortes (Bernabé 1993). The billeting of troops was especially costly in Catalonia during the war against France, to the point that this 'contribution' was another reason for the disaffection of the Catalans towards the House of Habsburg (Elliott 1963, chapter XIV).

Though there were differences and natural diversity, this type of mobilizations was very much present in America, from New Spain to the viceroyalty of Peru or Río de la Plata (Ruiz Ibáñez 2009). The formats employed ranged from the establishment of pacts between captains, Jesuits, and friendly Indians, who acted as sort of mercenaries in exchange for a range of concessions or advantages, to the formation of militias (Giudicelli 2009; Ariel and Svriz 2016). From the end of the sixteenth century, the urban militias were being rolled out in other territories and, indeed, across the Iberian world and its principal cities, most of them coastal, to the point that this was almost a global phenomenon (Ruiz Ibáñez 2009). ${ }^{25}$

The importance of all of this is difficult to exaggerate. As has been said (Chap. 4 above), it represented the military functioning of a composite monarchy. And it affects not only scholars' quantitative assessment of the war effort but also our understanding of the monarchy's overall debtsthat is, not just those of the King of Castile. This was also because a sizeable part of these operations continued to be paid for not only by the

${ }^{25}$ See the works by Descimon (1993) and M. Prak (2005). 
incomes of these kingdoms and corporations but also by increasing their debts. This is also important because it was a crucial phenomenon that, regardless of its quantitative impact, underlay the configuration of pacts that definitively affected the institutions and the political economy of the different territories.

In less than a century, the Habsburgs had managed to put together the two greatest European empires. In both cases the expansion had produced great advantages. But in both cases, this expansion had also been possible thanks to the projection upon them of informal networks that, despite their going beyond the family and not being only or purely of a familial character, had their transcendental weight in this institution. It could not be any other way, as the networks of relatives and those that could be built upon them played an essential role in this society. In fact they served as the basis of the expansion itself, which was also the result of the needs for expansion of social elites for whom the themes set out in the previous pages - family and extended family relationships, clientele systems, patronage between groups, friendship understood as a political expression and an economic action, a sense of local and religious identity-provided the internal structural forces that shaped the strategies for the reproduction of the social order. This would be fundamental to all developments.

In a brilliant essay written in 2007, Stuart Schwartz set out the dynamic of Portuguese commerce as the product of the clash between public institutions and merchants' private interests. The idea is excellent, and the above pages have attempted to reformulate it. The argument does not serve simply for the Portuguese empire. Nor should it be limited to commerce and merchants, since networks of trade were on many occasions only a part of informal and multifunctional webs that were much more extensive and widespread. And the outcome was logical: to the extent in which the institutions of the monarchy were imbued in this same social and ideological structure, the history of both empires can be understood as a process of continual perversion of the efforts towards centralization by the Crown. All of this stood at the base of a political economy in which the practices of rent-seeking, the capture of privileges, corruption, the continual use of privileged information of a very asymmetrical character, and so on would be essential components. It would be these networks, the very agents that had contributed towards the establishment of the empires, 
which would weaken the power of the Crown, which without doubt must be seen as the most important and the most powerful of all agents but, in the final analysis, simply an agent in these pacts. And this was so much more the case to the extent that the very process of globalization would end by turning upon those who had created it.

The deficiencies in the system of the Carrera de Indias and commercial licences as well as the need to attend to the necessities of possessions in America, Africa, and Asia were leading to a fall in the Crown's revenues on the peninsula. This drop in revenues affected the sophisticated edifice constructed by Charles V. Yet this situation did not imply a long-term reduction of global commercial traffic. Under these circumstances, intra-colonial commerce grew, and even the official traffic centred on Seville and Lisbon resisted better and longer than has often been thought. At the same time, through these cities or through direct or indirect contraband with the colonies, commercial networks centred outside of the peninsula, in such centres as Amsterdam, Mexico, Manila, the coastal areas of Brazil, and others, increased their participation in this traffic. This change, moreover, also resulted from the fact that competitor states such as England or the United Provinces were conscious that it was easier and cheaper to infiltrate Iberian markets than to affront the risks and the costs of protection and administration that the conquest of such vast territories would have entailed. A tentacular empire is attacked at the nodes of its tentacles.

Such a subtle process of invasion took place during the conflicts of the first half of the seventeenth century. Though the Thirty Years War was lived in Europe with great intensity, its extra-European dimension would bring out key elements in the working of the empire and the construction of the state. Far from being a narrowly European conflict, the war was a global phenomenon that compelled this composite global empire to mobilize in its peripheral areas. The consequent mobilizations, moreover, were far greater than is usually recognized when attention focuses only on flows of cash. Precisely because of its dimensions and characteristics, this conflict brought to light the limits of the military revolution and its effects upon the system for the mobilization of resources, which unsurprisingly were more appropriate for a composite monarchy than for a modern state (this latter assumption being the starting point for most visions). And it led to mobilizations in peripheral areas of this composite global empire that would be far greater than is usually recognized when the European dimension is the sole focus of attention. For all these reasons, war would 
shape and mark the equilibrium of the dominant coalitions, the political economy, and the path taken by the Iberian world, which was very different from the direction embarked upon by countries such as England. But, above all, it would lead to a process of dispersion of resources and even decentralization that would be decisive for the future of the empire. Local elites, particularly in America, would find in this situation the bases for more and more power of negotiation with the centre and for increasing autonomy. The next chapter will explore this aspect.

Open Access This chapter is licensed under the terms of the Creative Commons Attribution 4.0 International License (http://creativecommons.org/licenses/ by $/ 4.0 /$ ), which permits use, sharing, adaptation, distribution and reproduction in any medium or format, as long as you give appropriate credit to the original author(s) and the source, provide a link to the Creative Commons licence and indicate if changes were made.

The images or other third party material in this chapter are included in the chapter's Creative Commons licence, unless indicated otherwise in a credit line to the material. If material is not included in the chapter's Creative Commons licence and your intended use is not permitted by statutory regulation or exceeds the permitted use, you will need to obtain permission directly from the copyright holder.

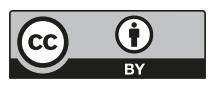

